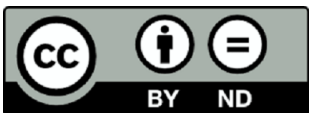

Andrea Mariani

Poznań

\title{
Aktywność jezuickich kapelanów nadwornych prowincji litewskiej. Między ustawodawstwem zakonnym a praktyką
}

\begin{abstract}
Zarys treści
Niniejszy artykuł dotyczy aktywności kaznodziejów, spowiedników i prywatnych nauczycieli z zakonu jezuitów na dworach królewskich i magnackich w dawnej Rzeczypospolitej. Pierwsza część pracy skupia się na zasadach regulujących działalność kapelanów nadwornych, określonych w II połowie XVI stulecia. Następnie zarysowany jest zbiorowy portret jezuickich kapelanów prowincji litewskiej w XVII i XVIII w. W ramach tych rozważań autor omawia wzajemne oddziaływanie Towarzystwa Jezusowego i jego dobroczyńców, a także próbuje określić, w jakim stopniu prawodawstwo zakonne było przestrzegane w badanym kontekście. Pomimo marginalizacji jezuitów litewskich na dworze królewskim w II połowie XVII w., liczba kapelanów nadwornych pozostała znacząca. Wynikało to z silnej obecności w kręgu najbardziej wpływowych rodów litewskich, takich jak Radziwiłłowie i Sapiehowie. Na stanowisko kapelana nadwornego byli powoływani zazwyczaj księża na początku kariery zakonnej. W większości przypadków urząd ten sprawowano przez stosunkowo krótki okres, co uprawnia do stwierdzenia, że stanowił on odskocznię do późniejszych awansów. O powołaniu na służbę dworską decydowała osobowość kandydata: magnaci oczekiwali bowiem lojalności i roztropności od swoich kapelanów. Pożądana była także znajomość języka francuskiego. Pochodzenie społeczne nie odgrywało natomiast większej roli. Mimo że nie każdy kapelan nadworny wchodził w skład duchownej klienteli magnatów, wielu z nich pełniło zadania niezwiązane ściśle z powołaniem zakonnym. Relacje z patronami miały niekiedy charakter emocjonalny, jak ukazuje się w świetle korespondencji.
\end{abstract}

Słowa klucze: Towarzystwo Jezusowe, Wielkie Księstwo Litewskie, Kościół rzymskokatolicki, dwory magnackie, administracja zakonna

Keywords: Society of Jesus, Great Duchy of Lithuania, Roman Catholic Church, aristocratic courts, administration of the Order

Specyficzna forma duszpasterstwa zakonnego wiązała się ze sprawowaniem funkcji spowiednika i kaznodziei na dworach władców lub innych wpływowych dostojników zarówno w średniowieczu, jak i w epoce nowożytnej. Szczególnym 
zaangażowaniem na tym polu wyróżniało się założone w 1540 r. Towarzystwo Jezusowe. Sukces jezuitów wynikał z ich wkładu w rozwój teologii moralnej, dyscypliny o charakterze praktycznym, która podejmowała kwestie tzw. kazusów sumienia, oraz z ich doskonałej znajomości dorobku kultury starożytnej, który w renesansie stał się niezbędnym elementem formacji męża stanu ${ }^{1}$. Dokładne rozeznanie obu tych problematyk, połączone $\mathrm{z}$ wszechstronną aktywnością jezuitów w sferze kulturowej, dawało im szansę na nawiązanie bliskich kontaktów z głównymi decydentami w życiu politycznym. W tym kontekście kapelani nadworni odgrywali pierwszoplanową rolę. Dla tych duchownych służba dworska wiązała się przede wszystkim z zapewnianiem opieki duszpasterskiej, a w dalszej kolejności edukacji przyszłych przedstawicieli elit. $Z$ jednej strony działalność ta tworzyła okazję do oddziaływania na penitentów lub wychowanków. Z drugiej zaś przebywanie jezuitów poza murami klasztornymi wywierało wpływ na ich pozycję $\mathrm{w}$ zakonie, a przez to na funkcjonowanie całego zgromadzenia. Bliższe spojrzenie na wymienione tu aspekty stanowi cel niniejszej pracy.

Ze względu na rozległość tematu zakres rozważań należy ograniczyć do utworzonej w $1608 \mathrm{r}$. prowincji litewskiej. Za tym wyborem przemawia specyfika realiów społecznych na wschodnich rubieżach dawnej Rzeczypospolitej, gdzie w XVI w. katolicyzm posiadał słabszą pozycję wobec dominującego prawosławia i szybko rozwijającego się ruchu reformacyjnego. Występowało tam również wyraźne zróżnicowanie wewnątrz stanu szlacheckiego. Właśnie wyłanianie się przewagi magnaterii, wyraźniejszej niż w Koronie, zmusiło jezuitów do dokonania głębokiej adaptacji własnego duszpasterstwa do potrzeb lokalnej elity. W ramach tego procesu pierwszoplanowe znaczenie przypadało kapelanom nadwornym.

Jednostki administracyjne zakonu należy traktować nie tylko jako organizacje terytorialne, ale również jako korporacje duchownych, którzy działali na danym obszarze geograficznym, podlegając równocześnie władzy tego samego przełożonego, zwanego prowincjałem. Prowincja litewska obejmowała nie tylko tereny Wielkiego Księstwa, ale również Warmię, Mazowsze i Podlasie oraz Inflanty i Kurlandię. W okresie maksymalnego rozrostu, w połowie XVIII w., należało do tej jednostki administracyjnej ok. 1100 zakonników i 35 większych placówek². Trudności, jakie sprawiała rozległość tych granic i liczebność personelu, zadecydowały w latach 1758-1759 o przeprowadzeniu podziału prowincji. Na skutek tej decyzji wyodrębniono prowincję mazowiecką obejmującą nie tylko terytorium Mazowsza, ale również znaczną część ziem ruskich Wielkiego Księstwa Litewskiego. Pomimo

\footnotetext{
${ }^{1} \mathrm{Na}$ ten temat zob.: R.A. Maryks, Saint Cicero and the Jesuits. The Influence of the Liberal Arts on the Adoption of Moral Probabilsm, Aldershot-Rome 2008; M. Turrini La coscienza e le leggi: morale e diritto nei testi per la confessione della prima età moderna, Bologna 1991.

${ }^{2} \mathrm{Na}$ temat rozwoju prowincji zob. A. Mariani, Personaleinsatz und -mobilität in der litauischen Provinz der Gesellschaft Jesu im 18. Jahrhundert, „Zeitschrift für Ostmitteleuropaforschung”, R. 63, 2014, z. 2, s. 163-213.
} 
tego podziału w niniejszym artykule traktuje się obszar dawnej prowincji litewskiej jako całość aż do kasaty Towarzystwa, która nastąpiła w 1773 r. Wśród czynników wpływających na aktywność kapelanów nadwornych prowincji litewskiej istotne stało się włączenie do niej domu profesów w Warszawie, później przekształconego w kolegium. Podporządkowanie placówki warszawskiej władzy prowincjała litewskiego miało podwójne znaczenie. $Z$ jednej strony zapewniło jezuitom litewskim możliwość nawiązania bliskich kontaktów z dworem królewskim oraz z magnatami rezydującymi $\mathrm{w}$ mieście stołecznym. $Z$ drugiej, ponieważ $\mathrm{w}$ przeciwieństwie do kolegiów domy profesów nie opierały się na stałej fundacji, lecz utrzymywały się z jałmużny, kapelani nadworni należący formalnie do tej placówki pełnili ważną rolę w gromadzeniu środków na rzecz współbraci.

W kontekście historiografii polskiej tematyka dotycząca kapelanów nadwornych została omówiona głównie w odniesieniu do średniowiecza i do wczesnej epoki nowożytnej ${ }^{3}$. Aktywność jezuitów pozostawała dotąd na marginesie uwagi polskich badaczy. Doczekały się osobnych opracowań sylwetki wybitnych postaci, których wkład w życie dworu królewskiego stanowił tylko jeden z przejawów szerzej zakrojonej działalności. Do tych zakonników można zaliczyć m.in. Piotra Skargę ${ }^{4}$, Macieja Laternę $e^{5}$, Antonio Possevina ${ }^{6}$ oraz Karola Maurycego Votę ${ }^{7}$. Tymczasem debata historiograficzna była zdominowana przez kwestię rzekomego wpływu politycznego jezuickich spowiedników królewskich, o czym świadczą choćby fragmenty klasycznej już pracy Stanisława Załęskiego ${ }^{8}$. Dotychczas nie powstało natomiast opracowanie o charakterze syntetycznym, przedstawiające tło

\footnotetext{
${ }^{3} \mathrm{Na}$ przykład badano działalność dominikanów na dworze Jagiellonów. Zob.: G. Głuch, Dominikańscy spowiednicy i kaznodzieje Jagiellonów, w: Studia nad historia dominikanów w Polsce, t. 3: Dominikanie w środkowej Europie w XIII-XV wieku. Aktywność duszpasterska i kultura intelektualna, red. J. Kłoczowski, J.A. Spież, Poznań 2002, s. 239-258; U. Borkowska, Królewscy spowiednicy, w: Ludzie - Kościót - wierzenia. Studia z dziejów kultury i społeczeństwa Europy Środkowej (średniowiecze - wczesna epoka nowożytna), red. W. Iwańczak, S.K. Kuczyński, Warszawa 2001, s. 173-194.

${ }^{4}$ Zob. m.in.: J. Tazbir, Piotr Skarga: szermierz kontrreformacji, Warszawa 1978; K. Drzymała, Ks. Piotr Skarga SJ 1536-1612, Kraków 1984; S. Obirek, Wizja kościoła i państwa w kazaniach ks. Piotra Skargi SJ, Kraków 1994; J. Tazbir, Skarga Piotr (1536-1612), w: Polski Stownik Biograficzny [dalej: PSB], t. 37, Kraków-Warszawa 1997, s. 35-43; Ks. Piotr Skarga SJ (1536-1612): życie i dziedzictwo: rok jubileuszowy, red. R. Darowski, S. Ziemiański, Kraków 2012.

${ }^{5}$ Zob. m.in. S. Cieślak, Marcin Laterna SJ (1552-1598): działacz kontrreformacyjny, Kraków 2003.

${ }^{6}$ Zob. m.in.: L. Szilas, Der Hofprediger Laterna, Possevino und der polnische Königshof. Eine Instruktion Possevinos aus dem Jahre 1583, „Archivum Historicum Societatis Iesu”, R. 40, 1971, nr 80, s. 391-420; M. Scaduto, La missione del nunzio. Due memoriali di Possevino ambasciatore, 15811582, „Archivum Historicum Societatis Iesu”, R. 49, 1980, nr 97, s. 135-160; J.P. Donnelly, Antonio Possevino S.J., as Papal Mediator between Emperor Rudolf II and the King Stephan Batory, „Archivum Historicum Societatis Iesu", R. 49, 2000, s. 3-56; Antonio Possevino SJ (1533-1611): zycie i dzieło na tle epoki, red. D. Quirini-Popławska, Kraków 2012.

7 Zob. m.in. S. Załęski, Vota i Sobieski, „Przegląd Powszechny” 1901, t. 72, s. 168-187, 1902, t. 73, s. 52-64, 206-220, 342-354.

${ }^{8}$ Idem, Jezuici w Polsce, t. 1, cz. 2, Lwów 1900, s. 502-506, t. 3, cz. 1, Lwów 1902, s. 59-75.
} 
normatywne i uwarunkowania, które cechowały pracę kapelanów nadwornych w dawnej Rzeczypospolitej. Brakuje też zbiorowego portretu wspomnianej grupy duszpasterzy. Zalążka takiego szerszego spojrzenia można upatrywać w monografii Stanisława Obirka, poświęconej jezuitom przebywającym na dworach Stefana Batorego i Wazów ${ }^{9}$. Aktywność jezuitów w kręgach magnackich i biskupich $\mathrm{w}$ dawnej Rzeczypospolitej dotychczas nie została zbadana. Potrzeba podjęcia tego zagadnienia jest uzasadniona znaczeniem politycznym i społecznym, które bogatsza warstwa szlachty zdobyła w dawnej Rzeczypospolitej. W związku ze wzmacnianiem się pozycji magnaterii władza zakonna przywiązywała coraz większą wagę do opieki duszpasterskiej nad jej przedstawicielami. Zainteresowanie było zresztą obopólne: często o przysłanie jezuickiego spowiednika zabiegali sami magnaci, którzy uważali członków Towarzystwa za zdolnych i ludzi świetnie wykształconych do sprostania ponadprzeciętnym wymaganiom, jakie stawiało życie dworskie.

$\mathrm{W}$ historiografii zachodnioeuropejskiej z kolei zainteresowanie jezuickimi kapelanami nadwornymi sięga połowy XIX w. ${ }^{10}$ Wśród licznych przyczynków omawiających działalność jezuitów na różnych dworach szczególnie wyróżniają się prace Roberta Bireleya, skupiające się na politycznym wymiarze aktywności jezuickich kapelanów nadwornych w czasie wojny trzydziestoletniej (1618-1648) ${ }^{11}$. Istnienie tak obszernych opracowań sprzyjało prowadzeniu analiz porównawczych, w który to nurt wpisuje się m.in. Ronnie Po-chia Hsia ${ }^{12}$. Przedmiotem uwagi stała się również jezuicka literatura religijna skierowana do dworów, która dobrze została zbadana m.in. na przykładzie traktatu pt. La Cour Sainte Nicolasa Caussina $^{13}$. Nieco słabiej rozpoznane są reakcje wewnątrz zakonu na życie dworskie

${ }^{9}$ S. Obirek, Jezuici na dworach Batorego i Wazów. Wplyw kapelanów dworskich i wychowawców książąt na postawy panujących i politykę państwa 1580-1668, Kraków 1996.

${ }^{10}$ Do najdawniejszych przyczynków należy ten poświęcony spowiednikowi Ludwika XIV François de Lachaise, oparty na bogatym warsztacie źródłowym. Zob. F.R. de Chantelauze, Le Père de La Chaize, confesseur de Louis XIV: Études d'histoire religieuse, lettres et documents inédits, ParisLyon 1859.

${ }^{11}$ R. Bireley, Maximilian von Bayern, Adam Contzen, S.J., und die Gegenreformation in Deutschland, 1624-1635, w: Schriftenreihe der Historischen Kommission bei der Bayerischen Akademie der Wissenschaften, t. 13, Göttingen 1975; idem, Religion and Politics in the Age of the Counterreformation: Emperor Ferdinand II, William Lamormaini, S.J., and the Formation of the Imperial Policy, Chapel Hill 1981; idem, The Jesuits and the Thirty Years War: Kings, Courts, and Confessors, Cambridge 2003.

${ }^{12}$ R. Po-chia Hsia, Jesuitische Hofprediger in Frankreich und Bayern im 17. Jahrhundert. Ein Vergleich, w: Religion Macht Politik. Hofgeistlichkeit im Europa der Frühen Neuzeit 1500-1800. 04.10.2011-07.10.2011, Wolfenbüttel, H-Soz-u-Kult, 07.12.2011, http://hsozkult.geschichte.huberlin.de/tagungsberichte/id=3937 [01.09.2015].

${ }^{13}$ Zob.: Nicolas Caussin: rhétorique et spiritualité à l'époque de Louis XIII, red. S. Conte, Münster 2006; V. Kapp, Un jésuite à la recherche du, grand homme’: La Cour Sainte de Nicolas Caussin, „Travaux de Littérature” 2005, t. 18, s. 179-194; idem, La théologie des réalités terrestres dans La cour sainte de N. Caussin, w: Les Jésuites parmi les Hommes aux XVIe et XVIIe siècles, red. G. Demerson, B. Dompnier, A. Regond, Clermont-Ferrand 1987, s. 141-152. 
jezuitów ${ }^{14}$. Inny aspekt, na który zwrócili uwagę dotychczasowi badacze - zazwyczaj na marginesie szerszych opracowań na temat historii sztuki - stanowi wkład jezuickich kapelanów nadwornych w kształtowanie programów ikonograficznych budynków sakralnych, których realizację podejmowano na zlecenie władcy ${ }^{15}$.

Przy prowadzeniu badań nad aktywnością kapelanów nadwornych powinno się uwzględnić odległość, jaka dzieliła teorię od praktyki rządów Towarzystwa. Oba te aspekty były ściśle ze sobą powiązane. Teoria, która znajdowała wyraz $\mathrm{w}$ prawodawstwie zakonnym, kształtowała się $\mathrm{w}$ odpowiedzi na naciski pochodzące z niższych poziomów administracji Towarzystwa, pozostającej w bliskich kontaktach z elitą lokalną notablów i dobroczyńców zakonu. Zasady sformułowane przez kurię generalną miały z kolei tworzyć ogólne ramy dla podejmowania decyzji $w$ różnych prowincjach. Istnienie takiego mechanizmu narzuca również podział źródeł wykorzystywanych w niniejszej pracy. Pierwszy aspekt znajduje odzwierciedlenie w wypowiedziach założyciela zakonu, a także w ogólnych przepisach regulujących działalność kapelanów nadwornych. Drugi, ukazujący, w jaki sposób pewne rozwiązania wdrażano na terenie poszczególnych prowincji, może być naświetlony za pomocą katalogów personelu, które w przypadku prowincji litewskiej przechowywane są w dziale „Lituania” Archiwum Rzymskiego Towarzystwa Jezusowego ${ }^{16}$, oraz innych materiałów o charakterze uzupełniającym, jak korespondencja i dzienniki sporządzane przez przedstawicieli elit. Dobry stan zachowania tego typu materiałów pozwala na opracowanie zestawień statystycznych dotyczących aktywności jezuickich kapelanów nadwornych.

\section{Kształtowanie się urzędu kapelana nadwornego i dotyczących go przepisów}

Genezy silnego zaangażowania jezuitów w kręgi dworskie należy upatrywać w wypowiedziach założyciela zakonu. W Ćwiczeniach duchownych św. Ignacy zauważał, że gdy chodzi o pożytek własnej lub cudzej duszy, wypowiadanie się

\footnotetext{
${ }^{14}$ M. Friedrich, Politikberatung durch Intellektuelle? Das Verhältnis des Jesuitenordens zu den frühneuzeitlichen Fürstenhöfen im Spiegel von Giulio Negronis Traktat „Aulicismus, sive de fuga aulae dissertatio", w: Intellektuelle in der Frühen Neuzeit, wyd. L. Schorn-Schütte, Berlin 2011, s. 175-209.

15 Taką rolę pełnił Ignazio Guarini, jezuita związany z dworem Augusta III, przy projektowaniu kościoła Świętej Trójcy w Dreźnie. Zob. Gaetano Chiaveri, der Architekt der katholischen Hofkirche zu Dresden, t. 1: Dresdner Beiträge zur Kunstgeschichte, wyd. E. Hempel, W. Krönert, Dresden 1955, s. 128.

${ }^{16}$ Dzieliły się one na roczne (catalogi breves), podające nazwisko zakonnika i sprawowane przez niego urzędy, i trzyletnie (triennales), które zawierały informacje m.in. na temat proweniencji geograficznej, wieku, cechy charakteru i umiejętności językowych. Dla opisu bibliograficznego zob. Polonica w Archiwum Rzymskim Towarzystwa Jezusowego, red. A. Bieś i in., t. 2: Lituania, Kraków 2003, s. 54-98, 226-232.
} 
przez zakonnika w kwestiach polityki i gospodarki nie jest próżne, mimo że nie przynależą one do kompetencji stanu duchownego ${ }^{17}$. Pierwszy spowiednik królewski został powołany jeszcze za życia św. Ignacego i za jego wyraźną zgodą. Doszło do tego w 1552 r. w Portugalii, gdzie król Jan III poprosił prowincjała lub jego zastępcę o regularne słuchanie spowiedzi. Uznając, że nie można pogodzić służby ubogim, która stanowi cel życia zakonnego, z przebywaniem na dworze, prowincjał Diego Míron udzielił królowi odpowiedzi odmownej, a następnie poinformował o tym generała zakonu. Święty Ignacy jednak nakazał objąć zaproponowane stanowisko, podając dwa powody. Po pierwsze, Towarzystwo powinno świadczyć posługę duszpasterską zarówno w kręgu wysoko, jak i nisko urodzonych, zwłaszcza wtedy, kiedy prośba pochodzi od hojnego dobroczyńcy zakonu. Po drugie, ze sprawowania wspomnianej funkcji wynika większe dobro i chwalebna służba Bogu ${ }^{18}$. W świetle tych uwag staje się zrozumiały punkt Konstytucji, w którym Ignacy wskazywał na potrzebę pozyskania przychylności nie tylko Stolicy Apostolskiej, ale również władców świeckich, szlachciców i innych wpływowych ludzi, których postawa „decyduje o otwieraniu lub zamykaniu drogi ku służbie Bożej i zbawieniu dusz"19. Jednocześnie św. Ignacy ostrzegał przed objęciem urzędów świeckich, które mogą odciągnąć uwagę od realizacji powołania zakonu. Pozostawało otwarte pytanie, jak zareagować w przypadku, gdy świecki władca lub dostojnik nakładał na zaufanego jezuitę obowiązki typowo świeckie. Konstytucje cechowały się pewnym rygoryzmem: wskazywały na konieczność zwalczania tej tendencji, nie zezwalając na żadne wyjątki ${ }^{20}$. W wypadku otrzymania beneficjum przez kaznodzieję lub spowiednika nadwornego wymuszano na nim wystąpienie z zakonu.

Kolejny problem związany ze sprawowaniem urzędu kapelana nadwornego stanowiły rezydowanie poza domem zakonnym i podróżowanie wraz z dworem

17 „Nie mówić słów próżnych. Mam na myśli takie słowa, które ani mnie, ani drugiemu nie przynoszą pożytku, ani też nie są ku temu skierowane. A zatem gdy się mówi w celu niesienia pomocy albo z tym zamiarem, aby pomóc duszy własnej lub cudzej, albo ciału, albo nawet $\mathrm{w}$ dziedzinie dóbr doczesnych, nigdy słowa nie są próżne. Tak samo, gdy ktoś mówi o rzeczach [nawet] obcych jego stanowi, np. gdy zakonnik mówi o wojnach albo o kupiectwie. Bo we wszystkim, co tu zostało wymienione, jest rzeczą zasługującą mówić w sposób dobrze uporządkowany, a znów grzechem jest mowa nieuporządkowana i bezużyteczna”. I. Loyola, Ćwiczenia duchowne, przeł. J. Ożóg, Kraków 1996, \$ 40.

${ }^{18}$ Według św. Ignacego zdrowie każdego członu jest istotne dla sprawności całego organizmu. W związku z tym powinno się szacować nadworne duszpasterstwo bardziej niż inne formy posługi duchowej, gdyż ze zdrowia głowy wynika ocalenie całego ciała. Zob. I. Loyola do D. Míron, Rzym, 1 II 1553, w: Obras Completas de San Ignacio de Loyola, red. I. Iparraguirre, wyd. 2, Madrid 1963, s. 803-806.

${ }^{19}$ I. Loyola, Konstytucje Towarzystwa Jezusowego wraz z przypisami Kongregacji Generalnej XXXIV oraz normy uzupetniające zatwierdzone przez tę samą Kongregację, Kraków 2001, § 823-824. Zob. też: ibidem, $\$ 337$.

${ }^{20}$ Ibidem, $\$ 263,591-592$. 
władcy lub dostojnika. Zjawisko to kolidowało z przestrzeganiem klauzury zakonnej, do której jezuiccy spowiednicy byli zobowiązani tak samo, jak współbracia. Wspomniany tu problem dotkliwie odczuwano na terenie Rzeszy Niemieckiej, gdzie książęta i biskupi rywalizowali w pozyskaniu jezuickiego kapelana nadwornego $^{21}$. W tej kwestii wypowiedziała się w $1565 \mathrm{r}$. druga kongregacja generalna. Zebrani w Rzymie jezuici ustosunkowali się do prośby biskupa augsburskiego Ottona Truchsessa von Waldburg, który domagał się obecności jezuickiego spowiednika przy swoim boku podczas wyjazdów. Odpowiedź ojców zabrzmiała dość kategorycznie: żaden jezuita nie powinien podróżować wraz z dostojnikiem będącym pod jego opieką duchową. Dekrety drugiej kongregacji generalnej zezwalały jednak na wyjątki pod warunkiem, że okres przebywania poza placówką jezuicką nie będzie dłuższy niż dwa miesiące ${ }^{22}$.

Obok wspomnianych aspektów organizacyjnych ważkim problemem stały się rzekome wpływy polityczne ojców Towarzystwa. W 1593 r. piąta kongregacja generalna wydała dekret zakazujący jezuitom ingerowania $\mathrm{w}$ sprawy doczesne. Sprecyzowanie oficjalnego stanowiska Towarzystwa w tej kwestii miało chronić jezuitów przed zarzutami, które skierowano pod adresem zakonu z powodu roli odgrywanej przez niektórych spowiedników w okresie wojen religijnych we Francji lub w przygotowaniach wyprawy Wielkiej Armady. Tekst był sformułowany bardzo kategorycznie: żaden jezuita nie powinien się mieszać w interesy władców ani też zajmować się racją stanu. Jezuitom nieprzestrzegającym tego zakazu grożono pozbawieniem urzędu, a nawet wydaleniem $z$ Towarzystwa ${ }^{23}$. Dekret wywołał niezadowolenie niektórych prominentnych jezuitów, takich jak Antonio Possevino, który wyrażał własne wątpliwości w broszurze pt. De ratione agendi in principum aulis ${ }^{24}$.

Opozycyjne nastroje w zakonie za rządów generała Klaudiusza Acquavivy zmusiły przełożonego Towarzystwa do ponownego zabrania głosu w tej kwestii ${ }^{25}$. Wydane przez niego rozporządzenie De Confessariis Principum z 1602 r., ratyfikowane przez szóstą kongregację generalną w 1608 r., sformułowało oficjalne stanowisko Towarzystwa na kolejne dziesięciolecia ${ }^{26}$. Cel tej instrukcji stanowiło maksymalizowanie korzyści płynących z pozycji kapelana nadwornego przy jednoczesnym ograniczaniu szkód, które mogły wyniknąć z tego typu działalności.

${ }^{21}$ Szerzej o tym zob. B. Duhr, Die Jesuiten an den deutschen Fürstenhöfen des 16. Jahrhunderts, Freiburg am Breisgau 1901.

${ }^{22}$ Institutum Societatis Iesu, t. 1, Praga 1757, s. 496, 707.

${ }^{23}$ Ibidem, s. 719.

${ }^{24}$ Zachował się również memoriał pt. Dubii proposti dal P. Possevino l'anno 1594 circa il decreto del non trattar cose di stato, Archivum Romanum Societatis Iesu [dalej: ARSI], Congregationes, nr 20b, f. 342-344.

${ }^{25}$ Institutum..., t. 2, s. 251.

${ }^{26}$ Ibidem, s. 259-263. 
Wiodąca zasada była następująca: Towarzystwo nie powinno narazić się dobroczyńcom, odmawiając im spowiednika, ani też zrezygnować z możliwości niesienia im pomocy duchowej.

Instrukcja określała przede wszystkim sposób zachowania spowiednika, którego celem było pozyskanie przychylności protektora nie dla siebie samego, lecz dla całego Towarzystwa. Powinien mieszkać wraz ze współbraćmi, przestrzegając zasad klauzury i ubóstwa zakonnego. Dlatego nie mógł przyjąć materialnych świadczeń od protektora, a w przypadku nalegania przez niego miał przekazać ewentualne podarki przełożonemu. Spowiednik powinien również regularnie odprawiać Ćwiczenia duchowne, żeby udział w życiu dworu nie wpłynął negatywnie na jego życie religijne. Ponadto nie wypadało mu przyjeżdżać zbyt często na dwór, lecz tylko na przyzwanie.

W kwestii politycznego zaangażowania jezuitów rozporządzenie Acquavivy było dość niejednoznaczne. Nawiązując do kanonów piątej kongregacji, zaznaczało, że spowiednik powinien się zajmować interesami, które wiążą się z sumieniem władcy, albo z dziełami pobożności i miłosierdzia. W kontekście rywalizacji z protestantyzmem nie można było jednak wykluczyć kwestii politycznych i interesów państwowych. Dbając o nie, spowiednik nie powinien sprawiać wrażenia, że wywiera jakikolwiek wpływ polityczny, ponieważ takie mniemanie szkodzi całemu Towarzystwu. Jednoznacznie zabraniano jezuickiemu kapelanowi ubiegania się o korzyści dla osób trzecich. Wskazywano także na to, że nie powinien służyć jako osoba przekazująca wytyczne władcy ani też nagany w jego imieniu. Konsekwencją tego założenia było stwierdzenie, że spowiednik winien pozostać neutralny zarówno wobec niepopularnych decyzji panującego, jak też walk fakcji dworskich. Na koniec rozporządzenie Acquavivy określało stosunki między spowiednikiem a władcą, zastrzegając, że kapelan ma pokazać temu ostatniemu instrukcję w chwili rozpoczęcia służby dworskiej. Wówczas panujący powinien wyrazić zgodę na to, że wysłucha jezuity wtedy, kiedy on będzie widział potrzebę zgłoszenia nadużyć i innych występków. Jeżeli władca nie będzie usatysfakcjonowany zdaniem spowiednika, może sięgać po rady dwóch lub trzech teologów, które spowiednik musi zaakceptować.

Późniejsze przypisy stanowiły jedynie uzupełnienie instrukcji z 1602 r. Interpretacja rozporządzenia Acquavivy była uzależniona od uwarunkowań występujących na dworach zachodnioeuropejskich. Siódma kongregacja generalna, obradująca na przełomie 1615 i 1616 r., doprecyzowała na przykład, w jakich politycznych interesach spowiednik nie powinien się wypowiadać ${ }^{27}$. Udział jezuitów w obradach publicznych nad tymi sprawami był wręcz zakazany. I tak pozostawało pewne pole

${ }^{27}$ Zabraniano spowiednikom zajmowania stanowiska wobec traktatów międzynarodowych, następstwa do tronu i wojen domowych w krajach sąsiednich. R. Bireley, The Jesuits and the Thirty Years War..., s. 30. 
manewru. Przez słowo „publiczny” rozumiano bowiem „oficjalny”, co pozwalało jezuitom pełnić nieformalną rolę doradców w rozmowach prywatnych. Ponadto, ze względu na trudną sytuację jezuitów w niektórych krajach, ograniczano tam zakres kompetencji kapelanów nadwornych, zakazując im zajmowania stanowiska w najbardziej delikatnych kwestiach ${ }^{28}$.

Wspólnym mianownikiem opisanych dotychczas przepisów była idea spowiednika jako członka dworu, jednakże niezaangażowanego w rząd państwa. Na tym tle należy spojrzeć zarówno na praktykę w obrębie danej prowincji zakonnej, jak i na indywidualne przypadki. Do stosowania takiego podejścia uprawnia dobry poziom znajomości prawodawstwa zakonnego wśród jezuitów z poszczególnych krajów. Wynikał on nie tylko $\mathrm{z}$ ogłoszenia przepisów w formie samodzielnego druku (taką funkcję pełnił właśnie tzw. Institutum), ale też z zapoznawania się z nimi przez scholastyków już podczas studiów ${ }^{29}$.

Oprócz tekstów normatywnych refleksja wokół funkcji i znaczenia duszpasterstwa nadwornego rozwijała się także $\mathrm{w}$ formie traktatów ${ }^{30}$. Punktem wyjścia dla zawartych w nich rozważań były zazwyczaj maksymy polityczne zaczerpnięte z Pisma Świętego, w których świetle utożsamiano spowiednika i kaznodzieję z prorokiem napominającym biblijnego władcę o swoich powinnościach ${ }^{31}$. Wyłaniało się z tej literatury kilka nurtów myślenia. Najbardziej znany z nich reprezentowali autorzy dążący do „chrystianizacji” dworu, czego przykładem jest wspomniane już dzieło Caussina. Podejście to opierało się niekiedy na wyidealizowaniu konkretnych przykładów historycznych, wśród których szczególną uwagę zwracano na dwór cesarza Teodozjusza ${ }^{32}$. Nie było to jednak jedyne podejście. W zakonie podnosiły się też głosy krytyczne wobec udziału jezuitów w życiu dworskim ${ }^{33}$. Tego typu wypowiedzi odzwierciedlały szeroko rozpowszechnioną postawę w kręgu Towarzystwa. Zgodnie z nią kapelani nadworni rzadko byli lubiani przez współbraci, a niekiedy kuria generalna uważała ich za niewygodnych.

${ }^{28} \mathrm{~W}$ porównaniu z dworami habsburskimi bardziej skrępowana była działalność francuskich spowiedników królewskich, o czym świadczy instrukcja generała Muzia Vitelleschiego z 1622 r. Ibidem, s. 54.

${ }^{29}$ Wydane po raz pierwszy w Antwerpii w 1635 r., Institutum Societatis Iesu doczekało się w XVIII w. aż czterech wydań: w 1702, 1705, 1709 oraz 1757 r. Obok tej publikacji na poziomie lokalnym krążyły również rękopiśmienne zbiory zawierające dekrety kongregacji i listy poszczególnych generałów. Zob. M. Friedrich, Der lange Arm Roms? Globale Verwaltung und Kommunikation im Jesuitenorden 1540-1773, Frankfurt am Main-New York 2011, s. 206-210.

${ }^{30}$ Dla analizy kilku ważnych tekstów z początku XVII w. zob. idem, Politikberatung..., s. 186-192.

${ }^{31}$ Zob. A. Contzen, Daniel seu de statu, vita, virtute magnatum atque aulicorum, Colonia Agrippina 1630.

${ }^{32}$ Zob. M. Rader, Aula Sancta Theodosii iunioris, S. Pulcheriae Sororis, Eudociae Uxoris Augustorum, Augusta Vindelicorum 1608.

${ }^{33}$ Zob. G. Negroni, Aulicismus, sive de fuga aulae dissertatio, Mediolanum 1626. Dla analizy tego tekstu zob. M. Friedrich, Politikberatung..., s. 192 n. 


\section{Liczebność i nazewnictwo kapelanów nadwornych prowincji litewskiej}

W dawnej Rzeczypospolitej pierwsi jezuiccy kapelani nadworni pojawili się w kręgu Stefana Batorego (1575-1586). Ich wpływy wzmocniły się jednak dopiero za panowania Wazów (1587-1668) ${ }^{34}$. Na tle wzrostu znaczenia magnaterii, która rywalizowała przepychem $\mathrm{z}$ dworem królewskim, zaczęli się pojawiać również kapelani na dworach biskupich i magnackich. Tendencja ta zaznaczyła się w Koronie w latach 20. XVII stulecia, przede wszystkim na dworach hierarchów kościelnych, aby w krótkim czasie rozszerzyć się na tereny Wielkiego Księstwa, gdzie rozpowszechniła się wśród urzędników świeckich ${ }^{35}$. Już wcześniej istniały bliskie kontakty między jezuitami a poszczególnymi przedstawicielami elit. Świadczy o tym choćby przypadek konwertyty Mikołaja Krzysztofa Radziwiłła „Sierotki”, który dobierał spowiedników i doradców spośród personelu ufundowanego przez siebie kolegium w Nieświeżu ${ }^{36}$. Jednak nie byli to jeszcze kapelani nadworni przebywający na stałe w bliskim otoczeniu tego protektora zakonu.

$\mathrm{W}$ porównaniu $\mathrm{z}$ krajami zachodnioeuropejskimi spowiednicy i kaznodzieje na dworach wysokich dostojników pojawili się stosunkowo późno, gdy prawodawstwo zakonne w tej materii było już w dużym stopniu ukształtowane. Na to zjawisko mogło wpłynąć kilka czynników: decydował niewątpliwie wzrost znaczenia magnaterii w okresie po rokoszu Zebrzydowskiego (1606-1609). Zahamował on próby wzmocnienia władzy królewskiej. Istotne było również kształtowanie się elity rządzącej składającej się przeważnie z katolików, z których część została pozyskana przez samych jezuitów w poprzednich dziesięcioleciach. Tej tendencji sprzyjała polityka Zygmunta III (1587-1632), który wyraźnie preferował wyznawców katolicyzmu przy rozdawaniu wakansów. Nie bez znaczenia musiał wreszcie być rozwój sieci placówek jezuickich i związany z nim wzrost liczebności personelu prowincji, który w II dziesięcioleciu XVII w. przekroczył próg 400 osób. W porównaniu z pierwszymi dziesięcioleciami aktywności zakonu w Rzeczypospolitej, gdy wobec próśb potencjalnych fundatorów przełożeni borykali się niedoborem księży, sytuacja Towarzystwa $\mathrm{w}$ drugiej połowie panowania Zygmunta III była o wiele korzystniejsza. Mając do dyspozycji dostateczną liczbę kapłanów, mogli oni przeznaczyć kilku z nich do służby na dworach biskupich i magnackich.

\footnotetext{
${ }^{34}$ S. Załęski, Jezuici..., t. 1, cz. 2, s. 502-515.

${ }^{35}$ Ibidem, t. 2, Lwów 1901, s. 543-545.

${ }^{36}$ Funkcję tę pełnił Jan Aland. Encyklopedia wiedzy o jezuitach na ziemiach Polski i Litwy 15641995, red. L. Grzebień, Kraków 1996, s. 5.
} 
Wykres 1. Liczba jezuickich kapelanów nadwornych, nauczycieli prywatnych i ich pomocników, należących do prowincji litewskiej

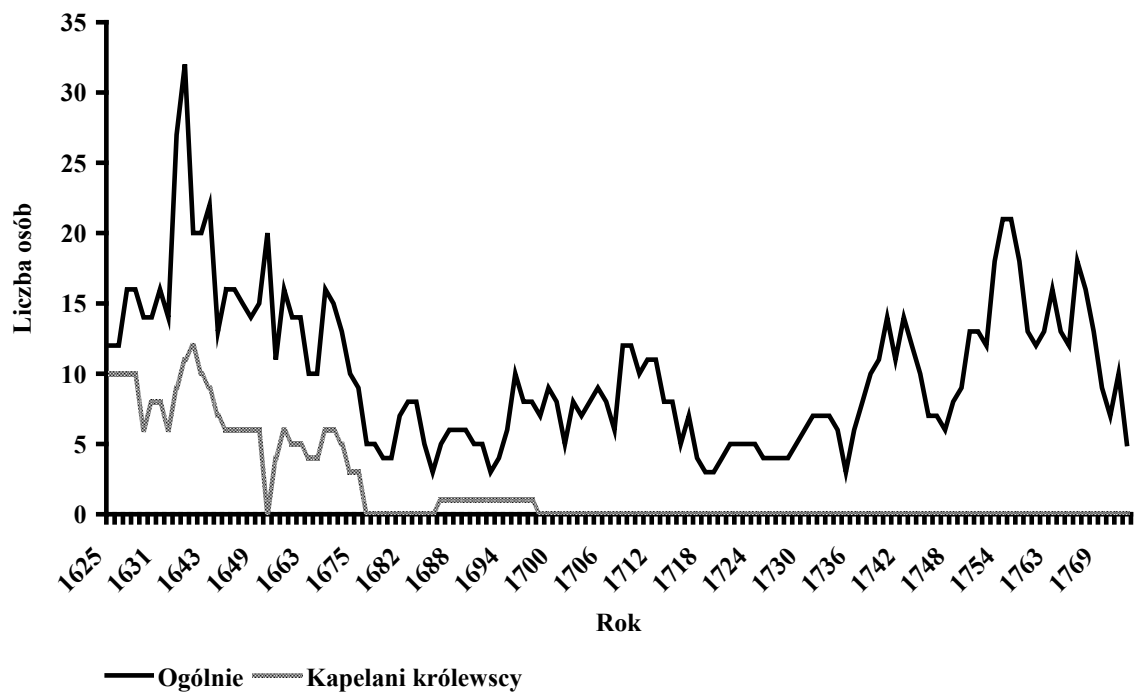

Źródło: ARSI, Lituania, nr 6, 56-60.

Od lat 20. XVII w. obecność jezuickich kapelanów w kręgu możnych stała się ważnym elementem aktywności zakonu. Zjawisko to trwało aż do kasaty Towarzystwa. Liczba kapelanów ulegała jednak pokaźnym fluktuacjom, gdyż na poszczególne lata do służby dworskiej przeznaczano od kilku do kilkudziesięciu zakonników. Jak widać na wykresie 1, okres najbardziej intensywnego zaangażowania litewskich jezuitów w życie dworów pokrywa się z panowaniem Wazów, gdy poziom liczebności wynosił stale ponad 15 osób, a w 1638 r. osiągnął rekordową liczbę - 32 zakonników. Aktywność jezuitów na tym polu słabła w ostatniej ćwierci XVII stulecia. Po niewielkim wzroście w okresie wielkiej wojny północnej (1700-1721) liczebność spadła ponownie na wcześniejszy poziom. Dopiero za panowania Augusta III (1733-1763) doszło do wzrostu liczby kapelanów, która osiągnęła szczyt w połowie lat 50. Dzięki obecności na dworach magnaterii Towarzystwo Jezusowe utrzymywało duży wpływ na elity świeckie nawet w okresie zaostrzania się konkurencji ze strony pijarów. Pojawia się przy tym zbieżność z reformą szkolnictwa zakonnego, którą jezuici podjęli, unowocześniając program nauczania i otwierając konwikty szlacheckie ${ }^{37}$. Niekorzystna tendencja zaznaczyła się dopiero po wygaśnięciu unii polsko-saskiej w 1763 r. Mogła ona wyniknąć z trudnej sytuacji politycznej powstałej w okresie elekcji ostatniego króla Stanisława Augusta (1764-1795) i początków jego panowania, a także z prześladowań,

${ }^{37}$ Zob.: S. Bednarski, Upadek i odrodzenie szkół jezuickich $w$ Polsce. Studium z dziejów kultury i szkolnictwa polskiego, Kraków 1933 (reprint: 2003), s. 254-464; K. Puchowski, Jezuickie kolegia szlacheckie Rzeczypospolitej Obojga Narodów. Studium z dziejów edukacji elit, Gdańsk 2007. 
których jezuici doznawali w Portugalii i monarchiach burbońskich. Warto wreszcie zwrócić uwagę na relatywną stabilność liczby kapelanów nadwornych w okresie pogłębiającego się militarnego kryzysu państwa polsko-litewskiego zarówno podczas powstania kozackiego, wojny polsko-szwedzkiej (1655-1660) i polsko-moskiewskiej (1654-1667), jak też wielkiej wojny północnej. W warunkach częściowej okupacji kraju protekcja dworów szlacheckich zapewniała jezuitom nie tylko ochronę fizyczną i źródła utrzymania, ale też możliwości prowadzenia szeroko zakrojonego duszpasterstwa. Zaangażowanie ojców Towarzystwa w życie dworów ulegało natomiast ograniczeniu w latach po wspomnianych konfliktach, gdy władze zakonne skupiały się na odbudowie placówek. W ten sposób można wyjaśnić niską liczbę kapelanów za panowania królów-rodaków oraz w drugiej połowie rządów Augusta II (1697-1733).

Na fluktuację w ogólnej liczbie kapelanów nadwornych należy spojrzeć również w kontekście zmieniającego się poziomu zaangażowania jezuitów litewskich w życie dworu królewskiego. Najsilniejsza była obecność jezuitów w kręgu Wazów. Na przykład u boku Zygmunta III przebywało ok. 10 zakonników, którzy do 1630 r. wchodzili w skład tzw. misji dworskiej z własnym superiorem na czele ${ }^{38}$. Oprócz spowiedników króla i królowej zaliczali się do tego grona również nauczyciele lub spowiednicy ich potomków oraz osobny kaznodzieja dworski. Liczebność misji uległa ograniczeniu u schyłku panowania Jana Kazimierza (1648-1668) i podczas krótkiego okresu rządów Michała Korybuta (1669-1673) z racji tego, że królowie ci nie doczekali się potomstwa. Jan III (1674-1696) z kolei korzystał w większym stopniu z opieki duszpasterskiej jezuitów prowincji polskiej, z którymi utrzymywał bliskie kontakty już jako jeden $\mathrm{z}$ najbardziej wpływowych magnatów koronnych ${ }^{39}$.

Stopniowy spadek znaczenia misjonarzy królewskich $\mathrm{w}$ ramach prowincji litewskiej przypieczętowało dojście do władzy Fryderyka Augusta I Wettina. Jako władca protestancki świeżo pozyskany dla katolicyzmu, August II nie utrzymywał wcześniej kontaktów z Towarzystwem. Korzystał więc początkowo z usług kapelanów swego poprzednika ${ }^{40}$. Dopiero w 1710 r., gdy otwarto w Dreźnie stałą stację misyjną, zaczęła kształtować się wokół króla grupa jezuitów, do której dobierano

${ }^{38}$ W późniejszym okresie ich nazwiska widniały wśród mieszkańców warszawskiego domu profesów. ARSI, Lituania, $\mathrm{nr}$ 6, passim.

${ }^{39}$ Do prowincji polskiej należał Adam Przyborowski, będący spowiednikiem Jana Sobieskiego w latach 1669-1683. Od 1684 r. funkcję tę sprawował Włoch Karol Maurycy Vota. Jedynym jezuitą litewskim współpracującym z dworem Jana III był Baltazar Dankwart, który jednak w katalogach występował jako kaznodzieja w kolegiacie św. Jana. Spowiednikiem Marii Kazimiery był natomiast Piotr Kostrzycki (1672-1687) z prowincji polskiej. Encyklopedia wiedzy o jezuitach..., s. 237.

${ }^{40}$ Wyróżniał się wśród nich Karol Maurycy Vota. O jego aktywności na rzecz Augusta II zob.: K. Piwarski, Pierwsze stosunki Augusta II ze Stolicą Apostolskq, „Polityka Narodów” 1937, t. 9, z. 6, s. 513-545; J. Staszewski, Stosunki Augusta II z Kuria Rzymska w latach 1704-1706, „Roczniki Towarzystwa Naukowego w Toruniu”, R. 71, 1966, z. 1, s. 10, 18; J. Kopiec, Między Altransztadem a Poltawą. Stolica Apostolska wobec obsady tronu polskiego w latach 1706-1709, Opole 1997, s. 62. 
zakonników pochodzących $\mathrm{z}$ różnych prowincji niemieckojęzycznego obszaru kulturowego ${ }^{41}$. Spośród nich wyznaczano spowiedników królewskich, którzy towarzyszyli władcy podczas pobytu na terenie Rzeczypospolitej. Opisany stan rzeczy utrwalił się za panowania Augusta III, który za sprawą żony Marii Józefy Habsburżanki utrzymywał bardzo bliskie kontakty z jezuitami ${ }^{42}$. Powrót rodaka na tron polski po śmierci Wettina nie zmienił pozycji jezuitów litewskich.

Inaczej przedstawiała się sytuacja za panowania Stanisława Augusta (17641795). Ostatniemu królowi Polski, wychowankowi teatynów, bliższa była formacja intelektualna Antoniego Marii Portalupiego, krzewiciela filozofii Chrystiana Wolffa, oraz duchowość nieco zabarwiona jansenizmem lazarysty Hiacynta Śliwickiego ${ }^{43}$. Jezuitów cenił natomiast ze względu na talent retoryczny i znajomość nauk. Zgodnie z tym podejściem korzystał z usług Śliwickiego jako spowiednika, podczas gdy jezuitów chętnie angażował jako kaznodziejów nadwornych. Urząd ten piastowali Sebastian Lachowski ${ }^{44}$, a po kasacie Towarzystwa były jezuita Ignacy Witoszyński ${ }^{45}$, obaj należący do prowincji małopolskiej. Ponadto w kontaktach z zakonnikami król kreował się na mecenasa, chętnie otaczając się jezuitami ${ }^{46}$.

Dodatkową przyczyną wzrostu liczebności misjonarzy dworskich w I połowie XVII w. było zjawisko charakterystyczne dla tego okresu, polegające na wysyłaniu na dwory, oprócz duchownych, również braci zakonnych $\mathrm{w}$ roli pomocników. Dotyczyło to zarówno misji na dworze królewskim, jak i otoczenia biskupów i magnatów. Obecność na danym dworze równocześnie dwóch członków Towarzystwa pozwala wysunąć hipotezę, że w pierwszych dekadach aktywności kapelanów nadwornych jezuici wydzieleni do tej posługi rezydowali poza klasztorami, przy czym brat zakonny, nieposiadający święceń kapłańskich, miał

${ }^{41}$ Zasadniczą rolę odgrywali członkowie prowincji czeskiej, do której formalnie należała misja drezdeńska, choć pojawiali się również przedstawiciele prowincji austriackiej, górnoniemieckiej i dolnoreńskiej. Dla zarysu dziejów tej placówki zob. B. Duhr, Geschichte der Jesuiten in den Ländern Deutscher Zunge im 18. Jahrhundert, t. 4, cz. 1, München-Regensburg 1928, s. 501-515. Dla składu osobowego zob. S. Załęski, Jezuici..., t. 3, cz. 2, Lwów 1902, s. 453-454.

${ }^{42}$ Zob. J. Staszewski, August III Sas, Wrocław 2010, s. 186, 268-270. Jedynym jezuitą prowincji litewskiej, blisko związanym z rodziną królewską, był Warmiak Fryderyk Idzell, który w latach 1759-1769 pełnił funkcje spowiednika księcia kurlandzkiego Karola Chrystiana. Encyklopedia wiedzy o jezuitach..., s. 225.

${ }^{43}$ Zob.: J. Fabre, Stanislas-Auguste Poniatowski et l'Europe des Lumières. Étude de cosmopolitisme, Paris 1952, s. 161-163; E. Rostworowski, Religijność i polityka wyznaniowa Stanisława Augusta, w: Życie kulturalne i religijność w czasach Stanisława Augusta Poniatowskiego, red. M.M. Drozdowski, Warszawa 1991, s. 11-24.

${ }^{44}$ E. Aleksandrowska, Lachowski Sebastian Fabian (1731-1794), PSB, t. 16, Wrocław 1971, s. $400-401$.

${ }^{45}$ L. Grzebień, Witoszyński Ignacy, w: Stownik polskich teologów katolickich, red. H.E. Wyczawski, t. 4, Warszawa 1983, s. 447-448.

${ }^{46}$ Aktywni w kręgu króla byli m.in. Franciszek Bohomolec i Jan Chrzciciel Albertrandi. Zob. S. Bednarski, op. cit., s. 469-470. 
pełnić funkcję stałego towarzysza. Powodów zaniechania tej praktyki nie sposób tłumaczyć na podstawie zachowanych źródeł. Można jednak sformułować kilka prawdopodobnych wyjaśnień. Zaangażowanie tzw. koadiutorów świeckich słabło po zakończeniu doby Wazów, gdy powoli następowała odbudowa struktur zakonu po głębokim kryzysie z połowy XVII stulecia. Aby wyrównać straty, wysoce pożądany był wkład braci zakonnych posiadających nieraz praktyczne umiejętności. Ze względu na spadek liczebności personelu, spowodowany wojną i zamknięciem szkół jezuickich, konieczny stał się powrót osób przebywających na dworach do macierzystych placówek.

Innym zjawiskiem, które należy odnotować, było stopniowe włączanie się jezuickich kapelanów nadwornych w struktury administracyjne zakonu. Przełomowe znaczenie miał pod tym względem wybuch niepokojów w połowie XVII w. O ile wcześniej jezuiccy kapelani przebywający na dworach magnackich wyjęci byli spod zwierzchnictwa miejscowych przełożonych, podlegając jedynie władzy prowincjała, o tyle od lat 50. zaczęto przydzielać ich do określonego kolegium. Nie oznaczało to wprowadzenia obowiązku rezydencji, gdyż w okresie okupacji rozległych połaci kraju wiele placówek przestało funkcjonować, a ich członkowie znajdowali schronienie w majątkach ziemskich lub u własnych rodzin ${ }^{47}$. Niemniej jednak, wobec trudności, które prowincjał spotykał w utrzymywaniu kontaktów z podwładnymi, przekazanie kontroli nad aktywnością kapelanów nadwornych rektorom winno usprawnić zarząd nad zakonem lub przynajmniej przeciwdziałać destrukcyjnemu wpływowi wojny. Wzmocnienie więzi między kapelanem nadwornym a placówką zakonną miało doniosłe znaczenie również dla poszczególnych kolegiów. Spowiednicy i kaznodzieje na dworach magnackich stawali się bowiem swoistego rodzaju rzecznikami interesów domów zakonnych, do których formalnie należeli. W związku z tym oni nie tylko wstawiali się za współbraćmi, ale też przekazywali miejscowym przełożonym „ofiary” swoich protektorów. Ich funkcja wpisywała się w uprzywilejowany stosunek, często o charakterze wielopokoleniowym, który łączył określoną placówkę z przedstawicielami danego rodu magnackiego. Ci ostatni występowali zazwyczaj jako fundatorzy i dobroczyńcy kolegium, które powstawało w pobliżu ich gniazda rodowego.

Ostatni aspekt, który pozwala uchwycić zmiany w sposobie pojmowania urzędu kapelana nadwornego, wiąże się z nazewnictwem. Na dworze Wazów, podobnie jak w przypadku innych dworów zachodnioeuropejskich, wyróżniano zazwyczaj trzy stanowiska: spowiednik (confessarius), kaznodzieja (concionator) oraz wychowawca książąt (magister lub institutor). Zachowanie odrębności obu pierwszych funkcji

${ }^{47}$ W 1657 r., w związku z okupacją Wilna przez wojsko moskiewskie, kilku jezuitów formalnie przypisanych do personelu akademii lub domu profesów znajdowało się u własnej rodziny: Karol Korsak przebywał u boku krewnego Romana, Paweł Laskowski na Mazowszu u rodziców, Władysław Rudziński zaś u matki. Stefan Żaboklicki z kolegium nieświeskiego znajdował się u siostry. Catalogus personarum 1657/1658, ARSI, Lituania, nr 56, k. 84v. 
polecano w literaturze religijnej z obawy, że podczas kazania kapelan ujawni grzech, o którym dowiedział się podczas spowiedzi ${ }^{48}$. Wbrew tym założeniom na dworach magnackich często łączono stanowiska spowiednika i kaznodziei ${ }^{49}$. U schyłku XVII w. kapelanów nadwornych zaczęto nazywać misjonarzami dworskimi (missionarius aulicus). Zmiana ta wiązała się z położeniem akcentu na misyjny charakter tego urzędu zakonnego. Odmienne nazewnictwo stosowano jedynie w przypadku kapelanów funkcjonujących w kręgu dostojników duchownych, których zwano teologami (np. theologus illustrissimi loci ordinarii). O misyjnym powołaniu kapelana nadwornego świadczy ponadto fakt, że niekiedy jezuita piastujący to stanowisko prowadził równocześnie duszpasterstwo w dobrach prywatnych świeckiego protektora bądź na terenie diecezji w przypadku hierarchy duchownego ${ }^{50}$.

Wyraźniej zdefiniowany był charakter prywatnego nauczyciela, którego fundamentalne zadanie polegało na udzielaniu lekcji z zakresu dyscyplin humanistycznych, sprawowanie opieki duchowej oraz nadzoru nad przebiegiem edukacji młodego magnata. Istnienie urzędu preceptora stawiało zamożną szlachtę na równi z władcami, na których prośbę tradycyjnie wyznaczano takich wychowawców. $\mathrm{W}$ przypadku prowincji litewskiej pierwszych nauczycieli prywatnych powołano już w połowie XVII w. w kręgu Radziwiłłów ${ }^{51}$. Przypadek tego rodu stanowił jednak przez długi czas wyjątek, ponieważ dopiero od lat 40 . XVIII stulecia zaczęli się pojawiać coraz częściej zakonnicy formalnie piastujący stanowisko preceptora w kręgu innych rodzin. Wypada zauważyć synchronizm z reformą szkolnictwa przeprowadzaną wówczas przez jezuitów. Wcześniej, gdy chlebodawca miał niepełnoletnie dzieci lub podopiecznych, ich wychowaniem zajmował się misjonarz dworski ${ }^{52}$.

${ }^{48}$ Takie stanowisko reprezentował m.in. Antonio Possevino w instrukcji De ratione agendi in principum aulis. S. Obirek, Jezuici na dworach Batorego i Wazów..., s. 6.

${ }^{49} \mathrm{~W}$ pierwszych latach przeważało określenie spowiednika. Pojawiał się też wyraz, jakoby jezuita przebywał „na dworze” (apud aulam) lub u czyjegoś boku (paenes). ARSI, Lituania, nr 6, 56, passim.

${ }^{50}$ Praktyka ta była powszechna w dobrach szlachty inflanckiej. Zob. A. Mariani, Jezuici w Inflantach i w Kurlandii (1700-1773). Między wielka polityka a elitą lokalna, „Zapiski Historyczne” 2012, t. 77, z. 4, s. 113-138. Występowała ona również na terenie Białej Rusi, o czym świadczy misja w Horodyszczach, uposażona przez Jadwigę z Zahorowskich Zamoyską. Działał tam w latach 1740-1753 kapelan nadworny fundatorki Marcin Kurzeniecki. B. Rok, Marcin Kurzeniecki (17051768). Jezuici wileńscy wobec Kościoła Unickiego w połowie XVIII wieku, w: Studia wschodnie, red. K. Matwijowski, Wrocław 1993, s. 51.

${ }^{51}$ Edukacją Michała Kazimierza, przyszłego podkanclerzego litewskiego, zajmowali się Maksym Wojciechowski (1644-1645) i Stefan Ozierko (1645-1648). Wojciech Przedziński uczył natomiast w latach 1666-1673 najstarszego syna wspomnianego magnata, Mikołaja Franciszka, oraz Michała, młodszego syna Michała Karola Radziwiłła, ordynata kleckiego i podczaszego litewskiego. Zob. Encyklopedia wiedzy o jezuitach..., s. 485, 547.

${ }^{52}$ Było to z reguły notowane w innego typu źródłach, takich jak nekrologia. Na przykład Marcin Przeradowski uczył synów hetmana Kazimierza Jana Sapiehy. Compendium vitae p. Martini Przeradowski, ARSI, Lituania, nr 62, f. 828. 
Praktykę mianowania prywatnych nauczycieli trudno było pogodzić z zasadą rezydowania $\mathrm{w}$ placówce zakonnej, którą starano się przestrzegać w przypadku kapelanów nadwornych. Wynikało to z faktu, że od preceptora oczekiwano nieustannego nadzoru nad wychowankiem, który zgodnie $\mathrm{z}$ wolą rodziców pozostawał zazwyczaj na dworze ${ }^{53}$.

W dawnej Rzeczypospolitej zacierały się granice między kapelanem nadwornym a wojskowym. Wspomniana tendencja wynikała $\mathrm{z}$ faktu, że magnaci nie tylko utrzymywali milicje prywatne, ale również byli głównymi dysponentami oddziałów wojskowych pozostających na żołdzie państwa. W katalogach osobowych określano tych kapelanów jako misjonarzy obozowych (missionarii castrenses). Do ich obowiązków należało „odprawianie mszy świętej, spowiadanie i komunikowanie żołnierzy oraz opatrywanie chorych sakramentami” ${ }^{4}$. W obliczu zagrożenia wojennego jezuici piastujący stanowisko spowiednika i kaznodziei nadwornego podejmowali niekiedy zadania właściwe dla kapelana wojskowego wśród podkomendnych dostojnika, u którego dotychczas służyli. Zdarzały się także zmiany w drugim kierunku: po zakończeniu działań zbrojnych misjonarze obozowi przechodzili na służbę ściśle dworską. Mimo że nadal utrzymywali kontakty $\mathrm{z}$ dotychczasowym protektorem, $\mathrm{w}$ momencie gdy stawali się misjonarzami obozowymi, jezuici przestawali być zobowiązani do przestrzegania zasad regulujących działalność kapelanów nadwornych, jak w przypadku mieszkania w klasztorze, i zaczynali podlegać innym przepisom. W ustawodawstwie zakonnym normowano kwestie związane z posługą duszpasterską wśród żołnierzy, podobnie jak w przypadku zwykłych misjonarzy: jedynym warunkiem, który stawiano, było uzyskanie zgody biskupa na prowadzenie misji na terenie danej diecezji ${ }^{55}$.

\section{Środowiska aktywności jezuickich kapelanów nadwornych}

Przeanalizowawszy zmiany w liczebności i nazewnictwie kapelanów nadwornych prowincji litewskiej, należy poświęcić kilka uwag tym rodzinom, wśród których

${ }^{53}$ Prowincjał litewski Stanisław Żaba wywierał presję, aby Antoni Alenkiewicz powrócił wraz z podopiecznym z dworu do kolegium w Iłłukszcie. Tam z powodu mniejszej liczby rozrywek dziecko miało osiągać lepsze postępy w nauce. W przeciwnym razie Żaba groził odwołaniem nauczyciela. Stanisław Żaba do Ludwika Konstantego Platera, Nowogródek, 4 VII 1765, Lietuvos Valstybès Istorijos Archyvas [dalej: LVIA], f. 1276, ap. 2, nr 110.

${ }^{54}$ J. Odziemkowski, Duszpasterstwo wojskowe $w$ dobie królów elekcyjnych, w: Historia duszpasterstwa wojskowego na ziemiach polskich, red. J. Ziółek, Lublin 2004, s. 142-143.

${ }^{55}$ Institutum Societatis Iesu nie zawierało bowiem żadnych odrębnych przepisów dla kapelanów wojskowych. To zagadnienie zostało szerzej omówione w artykule: A. Mariani, Udział jezuitów $w$ życiu milicji i korpusów radziwiłłowskich $w$ XVIII wieku, w: Studia nad staropolską sztukg wojenna, red. Z. Hundert, Oświęcim 2013, s. 196-197. 
trwale zaznaczała się obecność spowiedników z zakonu jezuitów. Abstrahując na razie od spraw związanych $\mathrm{z}$ mianowaniem na to stanowisko, trzeba zaznaczyć, że istniały dwa czynniki decydujące o podejmowaniu pracy duszpasterskiej w kręgu danej osoby lub rodu. Pierwszym była rola dobroczyńcy zakonu, drugim zaś jego wpływy polityczne. Te dwa aspekty współdziałały - choć w różnym wymiarze - w przypadku wyznaczenia każdego duszpasterza nadwornego. Przy ubieganiu się o przysłanie kapelana większe możliwości sukcesu miały osoby o dużych wpływach finansowych i politycznych, gdyż w ich protekcji władza zakonna upatrywała skutecznej ochrony interesów materialnych Towarzystwa. $\mathrm{Z}$ drugiej strony zapewnianie opieki duszpasterskiej zaprzyjaźnionym magnatom, którzy przeznaczyli fundusze na placówki jezuickie, stanowiło sposób odwzajemniania się za otrzymane łaski i utrwalania powstałych więzi.

Ogromne znaczenie dla jezuitów prowincji litewskiej posiadała katolicka gałąź rodu Radziwiłłów. Fakt ten jest zupełnie zrozumiały w świetle roli, którą na przełomie XVI i XVII w. odgrywał wspomniany już Mikołaj Krzysztof „Sierotka” jako fundator kolegium nieświeskiego i dobroczyńca kilku innych placówek jezuickich $^{56}$. Najwcześniej kapelani nadworni prowincji litewskiej pojawili się właśnie w kręgu jego najmłodszego syna Aleksandra Ludwika, marszałka wielkiego litewskiego ${ }^{57}$, oraz bratanka Albrychta Stanisława, kanclerza litewskiego. O ile pierwszy wiódł życie dalekie od rygorów kontrreformacji, o tyle drugi słynął z pobożności i zamiłowania do literatury religijnej, prowadząc intensywną działalność fundatorską, w której ramach uposażył m.in. kolegium jezuickie w Pińsku ${ }^{58}$. Utrzymywał on równocześnie aż kilku kapelanów nadwornych ${ }^{59}$, wśród których dwaj przebywali po jego śmierci w kręgu drugiej żony Krystyny z Lubomirskich ${ }^{60}$. Obecność jezuickich spowiedników na dworach radziwiłłowskich utrwaliła się również w przypadku dalszych potomków „Sierotki”, aż do kasaty Towarzystwa. Zjawiskiem charakterystycznym w przypadku kolejnych właścicieli Nieświeża, których wpływy na Towarzystwo daleko wykraczały poza granice prowincji litewskiej, było korzystanie z usług kapelanów nadwornych należących do prowincji polskiej. Praktyka ta nasiliła się w połowie XVII w. za sprawą ówczesnego ordynata

${ }^{56}$ T. Kempa, Mikołaj Krzysztof Radziwitł Sierotka (1549-1616) wojewoda wileński, Warszawa 2000, s. 152-155; T. Bernatowicz, Miles Christianus et peregrinus. Fundacje Mikołaja Radziwiłła „Sierotki" w ordynacji nieświeskiej, Warszawa 1998, s. 45-57, 70-73.

${ }^{57} \mathrm{Na}$ jego dworze przebywali Wojciech Slaski (1627-1630) i Jan Kasprowicz (1630-1639). Encyklopedia wiedzy o jezuitach..., s. 271, 623.

${ }^{58}$ Ibidem, s. 509; S. Załęski, Jezuici..., t. 4, cz. 3, Kraków 1905, s. 1363-1365. Zob. też: J. Seredyka, Pińsk Albrychta Stanisława Radziwiłła, w: Kultura polityczna w Polsce. Praca zbiorowa, t. 6: Litwa w polskiej tradycji i kulturze politycznej, cz. 1, red. M. Kosman, Poznań 2006, s. 37-49.

${ }^{59} \mathrm{Na}$ dworze kanclerza pracowali Paweł Wierzbicki (1624/1625), Szymon Berent (1626-1634), Adam Kołozebski (1634-1635), Krzysztof Zalewski (1638-1650) i Jan Szyłpa (1641-1643). Encyklopedia wiedzy o jezuitach..., s. 36, 294, 670, 735, 779.

${ }^{60}$ Byli to Bartłomiej Ziemblicki (od 1654 r.) i Maciej Starzyński (od 1652 r.). Ibidem, s. 643, 792. 
Michała Kazimierza, a szczególnie jego żony Katarzyny z Sobieskich, która jako siostra przyszłego króla utrzymywała bliskie kontakty z placówkami koronnymi. Ponieważ przebywała ona przeważnie w Białej Książęcej, sprzyjało to dobieraniu kapelanów nadwornych spośród personelu prowincji polskiej, a zwłaszcza z kolegium w Brześciu Litewskim, położonym niedaleko od wspomnianej rezydencji ${ }^{61}$. Takie podejście do wyboru kapelanów nadwornych stosował pierwotnie również syn Katarzyny, Karol Stanisław, który dopiero u schyłku życia zaczął korzystać z opieki duszpasterskiej jezuitów litewskich ${ }^{62}$. W okresie, gdy jezuici z terenów Wielkiego Księstwa byli mniej obecni w życiu Radziwiłłów nieświeskich, ich posługa kierowała się głównie do właścicieli Klecka. Własnego spowiednika miał na przykład Stanisław Kazimierz Radziwiłł, marszałek nadworny litewski ${ }^{63}$. Gdy po jego bezpotomnej śmierci ordynacja klecka przeszła w ręce Dominika Mikołaja, przyrodniego brata wspomnianego już Michała Kazimierza, jezuici zajmowali się nadal duszpasterstwem $\mathrm{w}$ kręgu jego rodziny ${ }^{64}$. Do ponownego zacieśnienia więzi z właścicielami Nieświeża doszło na tle stopniowego upadku pozycji tzw. linii kleckiej młodszej. Wśród postaci, które osiągnęły największe znaczenie, także w kontekście relacji z jezuitami, należy wymienić żonę kanclerza Karola Stanisława, Annę Katarzynę z Sanguszków, a także ich synów Michała Kazimierza „Rybeńkę” i Hieronima Floriana oraz wnuka Karola Stanisława „Panie Kochanku”65. Wśród mniej majętnych krewnych jedynie Albrycht, starosta rzeczycki, wysoko usytuowany wśród społeczności szlacheckiej województwa mińskiego dzięki korzystnemu małżeństwu, utrzymywał na swoim dworze kilku jezuickich kapelanów ${ }^{66}$.

${ }^{61}$ Mikołaj Mieleszko należał do personelu kolegiów w Brześciu Litewskim (1659/1660, 1665/1666) albo we Lwowie (1661-1665), w zależności od tego, czy Katarzyna rezydowała w Białej, czy w województwie ruskim. R. Grześkowiak, Wstęp, w: M. Mieleszko, Emblematy, wyd. i oprac. R. Grześkowiak, J. Niedźwiedź, Warszawa 2010, s. 58.

${ }^{62}$ Członkiem prowincji litewskiej był Michał Suffczyński, kapelan kanclerza w latach 1708-1713. Pozostali kapelani - Stanisław Bielicki (1693-1696), Mikołaj Golemowski (1703-1708) i Jan Jawgiełowicz (1713/1714) - należeli do prowincji polskiej. Encyklopedia wiedzy o jezuitach..., s. 45, 186, 234. W świetle katalogów rocznych początek działalności Bielickiego na dworze bialskim należy datować na rok 1693, a nie 1690. ARSI, Polonia, nr 45, f. $91 \mathrm{v}$.

${ }^{63}$ Był nim Michał Dąbrowski (1681-1686, 1689-1691). Encyklopedia wiedzy o jezuitach..., s. 121.

${ }^{64}$ Konrad Terpiłowski przebywał w latach 1691-1697 na dworze Dominika Mikołaja, a w latach 1702-1714 w kręgu jego syna Jana Mikołaja Aleksandra. Zob. ARSI, Lituania, nr 62, f. 873.

${ }^{65} \mathrm{Na}$ dworze kanclerzyny pracował Jan Poszakowski w latach 1722-1735. Z „Rybeńką” i jego kolejnymi żonami byli związani Feliks Wierzbicki (1730-1735), Mikołaj Kuczewski (1742-1765), Mikołaj Hryniewicki (1756-1758) i Józef Siesicki (1759-1767). Jako kapelan Hieronima Floriana służył Stanisław Klonowski w latach 1745-1755. Z Karolem Stanisławem „Panie Kochanku” był związany Michał Woronicz w latach 1754-1773. Encyklopedia wiedzy o jezuitach..., s. 223, 284, $341,532,617,735,759$.

${ }^{66}$ Byli to Antoni Borkowski (1759-1761, 1767-1768) i Jan Alojzy Szantyr (1761-1766). Ibidem, s. 58,657 . 
Drugą rodziną, która m.in. za pośrednictwem jezuickich kapelanów nadwornych wywierała ogromny wpływ na Towarzystwo Jezusowe, byli Sapiehowie. O ile w przypadku Radziwiłłów element patronatu kościelnego odgrywał niekiedy większą rolę niż znaczenie polityczne, o tyle w przypadku rodu herbu Lis wpływy na politykę państwa, zwłaszcza w XVII w., były decydujące. Obecność jezuickich kapelanów nadwornych sięgała lat 20. tego stulecia. Znaczącą rolę odgrywał wówczas kanclerz i hetman wielki litewski Lew Sapieha jako konwertyta i fundator kolegium w Brześciu Litewskim ${ }^{67}$. Jezuici zaangażowali się jako kapelani wojskowi podczas wojen ze Szwecją w latach 1621-1626 i 1626-1629, aby następnie stać się spowiednikami magnata ${ }^{68}$. Jeden $\mathrm{z}$ nich, Tomasz Jurgiewicz, związał swoje losy z synem Lwa, Kazimierzem Leonem, którego dwór otaczał opieką duszpasterską aż do śmierci. Obecność ojców Towarzystwa na dworach sapieżyńskich utrwaliła się w latach 50. i 60. XVII w., gdy własnych spowiedników miał hetman Paweł $J{ }^{69}$. Po przerwie w latach 70., na które przypadła hegemonia Paców, obecność jezuitów w kręgu Sapiehów nasiliła się ponownie w dwóch ostatnich dekadach stulecia. Wielu zakonników przewijało się w otoczeniu hetmana Kazimierza Jana $\mathrm{w}$ charakterze misjonarzy obozowych bądź spowiedników ${ }^{70}$. Obecność jezuitów zaznaczała się wyraźnie również w kręgu jego młodszego brata, podskarbiego Benedykta Pawła ${ }^{71}$. Godny podkreślenia jest fakt, że nawet po załamaniu się potęgi Sapiehów i poddaniu się ich pod protekcję Szwedów, jezuici nadal przydzielali duszpasterzy do ich dworów. Widać to choćby na przykładzie Michała Józefa, syna wspomnianego już Benedykta Pawła ${ }^{72}$, bądź Jana Kazimierza, syna Franciszka Pawła ${ }^{73}$.

${ }^{67}$ Ibidem, s. 72; S. Załęski, Jezuici..., t. 4, cz. 3, s. 1133.

${ }^{68}$ Byli to Tomasz Jurgiewicz (1625-1649) i Andrzej Lansedius (1629-1633). Encyklopedia wiedzy o jezuitach..., s. 256, 355.

${ }^{69}$ Funkcję tę pełnili Daniel Skarszewski (1663-1665) i Stanisław Tupik (1658-1666). ARSI, Lituania, nr 56, passim.

${ }^{70} \mathrm{~W}$ latach $1670-1678$, podczas piastowania urzędu wojewody połockiego, Jan Karnicki otaczał jego dwór opieką duszpasterską. Encyklopedia wiedzy o jezuitach..., s. 268. Po nominacji na hetmana, na dworze Kazimierza Jana pracował Jan Warschkeit (1687/1688). Ibidem, s. 719. Długoletnim konfidentem magnata był Baltazar Jaworski (1686-1706). Ibidem, s. 247; ARSI, Lituania, nr 62, f. 765. Na początku XVIII w. związali się z hetmanem Jan Oziębłowski (1702-1710) i Franciszek Symonowicz (1709-1715). Encyklopedia wiedzy o jezuitach..., s. 485, 655. Po śmierci Kazimierza Jana Piotr Skockiewicz pełnił funkcję spowiednika jego żony Antoniny z Waldsteinów (1721-1728). Ibidem, s. 621; Diariusz Józefa Stanisława Sapiehy, Biblioteka Narodowa [dalej: BN], Biblioteka Ordynacji Zamojskiej, nr 941, s. 10, 15.

${ }^{71}$ Z podskarbim przez dłuższy czas związany był Sebastian Limanowicz (1684-1707), który w latach 1695-1700 występował w katalogach prowincji litewskiej, w pozostałych latach zaś polskiej. ARSI, Lituania, nr 57, passim; ARSI, Polonia, nr 69, f. 106. Zob. też: Encyklopedia wiedzy o jezuitach..., s. 364 .

${ }^{72}$ Dworowi pisarza polnego zapewniał opiekę duszpasterską Jerzy Berent. Catalogus personarum 1709/1710, s. 8, ARSI, Lituania, nr 57.

${ }^{73} \mathrm{U}$ starosty bobrujskiego pracował w latach 1711-1717, 1718/1719, 1720-1722 Andrzej Pawłowski. Ibidem, passim. 
Zaangażowanie jezuitów litewskich zaczęło słabnąć dopiero w latach 20. i 30. XVIII w. na tle stopniowego upadku pozycji rodu. Tendencja ta nie wykluczała obecności kapelanów nadwornych w kręgu pojedynczych przedstawicieli familii. Ważny dla jezuitów litewskich był na przykład dwór generała artylerii litewskiej Kazimierza Leona Sapiehy ${ }^{74}$. Jan Fryderyk, kanclerz wielki litewski, najbardziej znaczący przedstawiciel rodu $\mathrm{z}$ tego okresu, korzystał natomiast $\mathrm{z}$ usług kapelanów prowincji polskiej, przeważnie związanych z kolegium w Brześciu Litewskim, na rzecz którego ufundował misję w Kodniu ${ }^{75}$.

Podczas gdy jezuiccy kapelanie nadworni angażowali się trwale w życie Radziwiłłów i Sapiehów, obecność spowiedników w kręgu innych rodów zamykała się w stosunkowo wąskich ramach czasowych. Można tu przytoczyć kilka przykładów. W połowie XVII w. władze zakonne wysyłały kapelanów na dwory Gosiewskich. Ogromne zasługi dla rozwoju zakonu położył wojewoda smoleński Aleksander, który ufundował placówki w Dyneburgu, Witebsku i Smoleńsku ${ }^{76}$. $\mathrm{Na}$ jego dworze jezuicki kapelan nadworny był aktywny od lat 30 . XVII w. ${ }^{77}$ Później zakonnicy pojawiali się w kręgu obu jego synów: Krzysztofa ${ }^{78}$ i Wincentego $^{79}$. Z kolei zaangażowanie jezuitów w krąg Paców przypadło na okres nasilenia się ich aktywności politycznej. Kapelanów utrzymywali zarówno hetman Michał Kazimierz ${ }^{80}$, jak i biskup wileński Mikołaj Stefan ${ }^{81}$. Do odbiorców posługi duszpasterskiej jezuitów w latach 60 . XVII stulecia zaliczał się również Cyprian Brzostowski ${ }^{82}$, który kilkanaście lat później przeznaczył stałe uposażenie dla placówki w Mińsku ${ }^{83}$.

W XVIII w. nowe rody korzystały z posługi duszpasterskiej jezuitów. Wyróżniali się wśród nich przede wszystkim Wiśniowieccy, którzy dopiero zyskiwali na znaczeniu na terenie Wielkiego Księstwa Litewskiego. Jezuici występowali

${ }^{74}$ Należał do niego Ignacy Gierłowicz (1738-1739). Wychowaniem jego dzieci zajmowali się Franciszek Judtz (1739-1741) i Ludwik Bemfelt (1742-1746). Ibidem, nr 58, passim.

${ }^{75}$ Encyklopedia wiedzy o jezuitach..., s. 289-290; S. Załęski, Jezuici..., t. 4, cz. 3, s. 1147.

${ }^{76}$ Encyklopedia wiedzy o jezuitach..., s. 139, 626, 749; S. Załęski, Jezuici..., t. 4, cz. 3, s. 1098, 1312, 1409.

${ }_{77}$ Był nim Stanisław Kosiński (1634-1637). Encyklopedia wiedzy o jezuitach..., s. 307.

${ }^{78}$ Wilhelm Buccius pracował na dworze Krzysztofa, wojewody smoleńskiego. Catalogus personarum 1643, kol. 8, ARSI, Lituania, nr 56. Po jego śmierci opiekę duszpasterską nad żoną zapewnił Tomasz Drzewicki (1645-1648). Encyklopedia wiedzy o jezuitach..., s. 133.

${ }^{79}$ Kapelanami podskarbiego byli Walenty Młodziesius (1652-1656) i Andrzej Dyndowicz (16551659). Losy uwięzionego przez Rosjan magnata dzielił Samuel Kuderowski w latach 1660-1662. Ibidem, s. 139, 342, 432.

${ }^{80} \mathrm{~W}$ okresie piastowania urzędu hetmana polnego na jego dworze przebywał Andrzej Rybski (1665-1667). Catalogus personarum 1665/1666, s. 14, ARSI, Lituania, nr 56. Później korzystał z usług Marka Grabena (1672-1680). Encyklopedia wiedzy o jezuitach..., s. 191.

${ }^{81}$ Jego spowiednikiem był Stanisław Tupik (1674-1679). Ibidem, s. 703.

82 Pełnili tę funkcję Stanisław Skorobohaty (1661-1662) i Marcjan Kołakowski (1666-1669). Ibidem, s. 293, 622.

${ }^{83}$ Ibidem, s. 425; S. Załęski, Jezuici..., t. 4, cz. 4, s. 1505. 
w otoczeniu obu braci: Janusza Antoniego ${ }^{84}$ i Michała Serwacego ${ }^{85}$. Podczas gdy obaj przysłużyli się zakonowi jako fundatorzy placówki w Krzemieńcu, na terenie prowincji polskiej, drugi był dobroczyńcą kolegium pińskiego i rezydencji w Słonimiu ${ }^{86}$. Wśród rodów magnackich bliżej związanych z Wielkim Księstwem na wzmiankę zasługują Ogińscy. Obecność jezuickich kapelanów nadwornych w ich kręgu, a w szczególności Marcjana ${ }^{87}$ i Kazimierza Dominika $^{88}$, zaznaczyła się w latach 20. XVIII w. wskutek osłabienia pozycji Sapiehów. Niepoślednie znaczenie jako miejsca działalności jezuickich spowiedników posiadały również dwory przedstawicieli kolejnego pokolenia rodu: Ignacego ${ }^{89}$, Stanisława ${ }^{90}$ i Tadeusza ${ }^{91}$.

Pomimo ulegania wpływom górującej w danym momencie fakcji magnackiej, władze zakonne szczególnie dbały o przydzielanie kapelanów nadwornych różnym stronom biorącym udział w walce. Starania te wyraźnie odzwierciedla sytuacja podczas wielkiej wojny północnej, gdy obok przywódców partii sapieżyńskiej własnych spowiedników mieli również stronnicy republikańscy. Oprócz wspomnianych już braci Wiśniowieckich zaliczali się do nich biskup wileński Konstanty Kazimierz Brzostowski ${ }^{92}$, Marcjan Dominik i Wincenty Piotr Wołłowiczowie ${ }^{93}$, Dominik Mikołaj Słuszka ${ }^{94}$ oraz Krzysztof Zenowicz ${ }^{95}$.

Istotnym aspektem, który należy odnotować, była obecność jezuickich duszpasterzy wśród ludzi pogranicza wyznaniowego. W XVII w. własnych kapelanów utrzymywał Jan Teodor Schlieben, jeden z przywódców opozycji antyelektorskiej w Prusach Książęcych, który w 1670 r. zbiegł do Rzeczypospolitej. Nawróciwszy się na katolicyzm, został wojewodą inflanckim z nadania Jana III i zasłynął jako

${ }^{84}$ Jego spowiednikiem był Krzysztof Puciłowski (1696-1707). Encyklopedia wiedzy o jezuitach..., s. 553.

${ }^{85}$ Pełnili tę funkcję Andrzej Narewicz (1700-1711, 1716-1731), Kazimierz Brzozowski (1732-1736) i Mikołaj Krüger (1736-1743). Ibidem, s. 73, 334, 450.

${ }^{86}$ S. Załęski, Jezuici..., t. 4, cz. 3, s. 1373, 1375, cz. 4, s. 1673.

${ }^{87} \mathrm{~W}$ kręgu kasztelana, a następnie wojewody witebskiego występował Piotr Truchoniewicz (17231725). Encyklopedia wiedzy o jezuitach..., s. 701.

${ }^{88} \mathrm{Na}$ dworze wojewody trockiego, a następnie wileńskiego prowadzili duszpasterstwo Franciszek Piszczański (1728/1729) i Jerzy Wolski (1729-1734). Ibidem, s. 757.

${ }^{89} \mathrm{Na}$ dworze Ignacego przebywał Mikołaj Trzebicki (1739-1747). Ibidem, s. 702.

${ }^{90}$ U Stanisława służyli Józef Brzozowski (1739/1740) i Feliks Jonakowski (1743-1751). Ibidem, s. $73,254$.

${ }^{91} \mathrm{Na}$ dworze Tadeusza pracowali Wiktor Pióro (1738-1742), Józef Oziębłowski (1745-1748) i Antoni Żyzmiński (1748-1751). Ibidem, s. 486, 514, 806.

${ }^{92}$ Byli to po kolei Andrzej Odoyski (1706-1713), Piotr Puzyna (1713-1717), Józef Horodecki (1717-1718) oraz Adam Minkiewicz (1719-1722). Ibidem, s. 221, 425, 471, 555.

${ }^{93}$ Byli to Daniel Zierowski (1710-1711), Jan Szapiel (1715-1716) i Mikołaj Mroczkowski (17161717). Ibidem, s. 443, 657, 792.

${ }^{94}$ Piastował ten urząd Hieronim Czerński w latach 1702-1712. Ibidem, s. 112.

${ }^{95}$ Był to Jerzy Elert w latach 1708-1716. Ibidem, s. 147. 
dobroczyńca misji w Świętej Lipce ${ }^{96}$. Do niego była skierowana posługa kilku jezuitów związanych z kolegium w Reszlu ${ }^{97}$. W XVIII w. zaznaczyła się działalność jezuickiego spowiednika w kręgu Bogusława Niezabitowskiego, starosty propojskiego i późniejszego kasztelana nowogródzkiego ${ }^{98}$. Wyrosły w środowisku kalwińskim (jego dziadek Stanisław przeszedł na to wyznanie podczas służby u Bogusława Radziwiłła), Bogusław powrócił na łono Kościoła rzymskiego, czemu zawdzięczał krzesło senatorskie. Utrzymywał jednak nadal bliskie relacje gospodarcze i towarzyskie z ewangelikami, m.in. za sprawą żony Marianny z Orzechowskich, która była gorliwą wyznawczynią kalwinizmu ${ }^{99}$. U schyłku badanego okresu wzrosło także zaangażowanie kapelanów nadwornych w życie elit na ziemiach Inflant i Kurlandii. Zamożna szlachta katolicka hojnie wspierała misjonarzy poruszających się po terenie, a w późniejszym okresie zakładała misje jezuickie we własnych dobrach ${ }^{100}$. Wśród tych rodzin wyróżniali się Borchowie ${ }^{101}$. Hylzenowie ${ }^{102}$ i Platerowie ${ }^{103}$, którzy przeszli na katolicyzm w XVII w. Oprócz tych rodów, zajmujących pierwszoplanową pozycję wśród elit dawnej Rzeczypospolitej, jezuickich kapelanów nadwornych utrzymywali też właściciele ziemscy części Inflant pod panowaniem rosyjskim, jak konwertyta Wilhelm Henryk Lieven ${ }^{104}$, oraz dowódcy armii carskiej ${ }^{105}$.

Obok dworów magnackich istotne znaczenie dla aktywności jezuitów miały również siedziby biskupie. Nie sposób tu dostarczyć pełnego wykazu nazwisk tych

${ }^{96}$ A. Kamieński, M. Nagielski, Schlieben Jan Teodor (1638-1695), PSB, t. 35, Warszawa 1994, s. $520-522$.

${ }^{97} \mathrm{Na}$ dworze Schliebena pracowali w latach 1674-1676 Jan Zaręba i Zygmunt Marquardt. Prawdopodobnie w kręgu wojewody przewijali się również Jakub Eler (1686-1688), Marcin Kretzmer (1689-1691) oraz Paweł Zembrzuski (1693-1695). ARSI, Lituania, nr 56, passim.

${ }_{98}$ Był nim Jozafat Sokołowski w latach 1729-1738. Ibidem, nr 58, passim.

99 A. Sajkowski, Niezabitowski Bogusław (zm. 1739), PSB, t. 23, Wrocław 1978, s. 97.

${ }^{100} \mathrm{Na}$ przykład Hylzenowie uposażyli misje w Dagdach i w Kownacie. Platerowie założyli stacje misyjne w Indrycy i w Krasławiu, Borchowie zaś w Prelach. A. Mariani, Jezuici w Inflantach..., s. $129-130$.

${ }^{101}$ Misjonarzami Borchów byli Szymon Ebert (1695/1696), Jan Klimowicz (1696/1697), Jakub Piplewski (1698-1701), Franciszek Symonowicz (1701/1702) i Michał Ratkowski (1702/1703). ARSI, Lituania, nr 57, passim.

${ }^{102}$ Na dworze Jana Augusta przebywali Franciszek Radziszewski (1754-1772) jako kapelan i Karol Wyrwicz jako nauczyciel jego syna Józefa (1751-1757). Encyklopedia wiedzy o jezuitach..., s. 560, 773. W kręgu Jerzego Mikołaja, brata Jana Augusta i biskupa smoleńskiego, pracowali Antoni Skorulski (1748/1749), Stanisław Karwacki (1749/1750) i Jakub Lingkenheier (1763/1764). Ibidem, s. 270, 364, 622.

${ }^{103}$ Na dworze Konstantego Ludwika Platera pracowali Rafał Hempel (1754-1758), Antoni Alenkiewicz (1763-1768) i Tadeusz Szabłowiński (1767-1773). Ibidem, s. 7, 212, 656.

${ }^{104}$ Funkcję tę pełnił Jakub Perynet (1753-1755), później misjonarz w dobrach Lievenów. Jako wychowawca synów Wilhelma Henryka pracował Jakub Jacewicz (1753-1758). Fontes Historiae Latviae Societatis Iesu. Latvijas vēstures avoti jezuītu ordena archivos, red. J. Kleijntjenss, t. 2, Rīga 1941, s. 396.

105 W kręgu Andreja de Brilly, generała włoskiego pochodzenia, pracowali Józef Kraus (1750/1751), Maciej Bercekiewicz (1751/1752) i Józef Bartsch (1753/1754). Ibidem, s. 396-398. 
osób, które w badanym okresie pracowały we wspomnianym środowisku, tym bardziej że czas sprawowania tej funkcji był zazwyczaj krótszy niż w przypadku dworów magnackich. Warto jednak podać kilka przykładów. Przez cały badany okres silna była obecność jezuitów w kręgu kolejnych biskupów wileńskich ${ }^{106}$. Fakt ten nie powinien dziwić, gdy bierze się pod uwagę, iż piastowali oni najwyższy urząd senatorski w Wielkim Księstwie, a także zarządzali najbardziej rozległą diecezją na terenie dawnej Rzeczypospolitej. Kolejne miejsce po wileńskich zajmowali ordynariusze żmudzcy. Wśród nich w XVII stuleciu konsekwentnie utrzymywał własnych spowiedników Jerzy Tyszkiewicz ${ }^{107}$. Zaangażowanie jezuitów unaoczniało się również w przypadku biskupów koronnych. Własnych kapelanów mieli m.in. Michał Działyński ${ }^{108}$, Marcin Szyszkowski ${ }^{109}$ oraz Tomasz Ujejski ${ }^{110}$. Ten ostatni pod koniec życia zrezygnował z biskupstwa kijowskiego w celu wstąpienia do Towarzystwa ${ }^{111}$. W XVIII w. Józef Andrzej Załuski miał przez dłuższy czas spowiednika z zakonu jezuitów, angażującego się w rozmaite inicjatywy kulturalne protektora ${ }^{112}$. Jezuiccy kapelani występowali także $\mathrm{w}$ otoczeniu wybitnych mężów stanu, jak choćby Mikołaja Prażmowskiego ${ }^{113}$, Andrzeja Olszowskiego ${ }^{114}$ i Andrzeja Chryzostoma Załuskiego ${ }^{115}$.

${ }^{106} \mathrm{Na}$ dworze Eustachego Wołłowicza pracował Sebastian Roman (1627-1629). Spowiedników mieli także Jan Zawisza (Wojciech Kojałowicz w latach 1656-1661), Mikołaj Stefan Pac (Stanisław Tupik w latach 1674-1679), Konstanty Kazimierz Brzostowski, Michał Jan Zienkowicz (Franciszek Grzymała w latach 1731-1734, Jan Juraha w latach 1734-1746, Stefan Wierzbicki w latach 1746-1758 i Józef Skorulski w latach 1758-1762) oraz Ignacy Jakub Massalski (Wacław Wiażewicz w latach 1766-1770). ARSI, Lituania, nr 6, 56-58, passim.

${ }^{107}$ Biskupowi żmudzkiemu zapewniali posługę duszpasterską Jan Jachnowicz (1638-1639), Michał Kownacki (1634-1641, 1642-1644) i Adam Sobolewski (1645-1648). Encyklopedia wiedzy o jezuitach..., s. 234, 313, 628 .

108 Jako sufragan warmiński korzystał on z usług Andrzeja Bruchmana (1629-1633). Po objęciu biskupstwa kamienieckiego jego teologiem był Bartłomiej Hempel (1648-1650). Ibidem, s. 70, 212.

${ }^{109}$ W kręgu Szyszkowskiego przewijali się Jan Strubicz (1634-1643), Jerzy Erenst (1642-1643) i Paweł Kozłowski (1636-1637). Ibidem, s. 149, 316, 649.

${ }^{110}$ Na dworze Ujejskiego pracowali Wojciech Szygowski (1658/1659), Szymon Wdziekoński (16621671) i Jan Świerczewski (1671-1677). Ibidem, s. 670, 678, 727.

${ }^{111}$ Ibidem, s. 709.

${ }^{112}$ Funkcję tę pełnił w latach 1750-1766 Michał Richowei, który brał udział m.in. w przygotowaniu czterotomowego Zbioru dziejopisów polskich (Warszawa 1764-1768). Zob. „Wiadomości Uprzywilejowane Warszawskie", (Warszawa) 29 XII 1762, Supplement, nr 104. Misjonarzem dworskim biskupa kijowskiego był także Franciszek Bohomolec w roku szkolnym 1760/1761. Ogólnie na temat relacji Załuskiego z jezuitami zob. L. Grzebień, Józef Andrzej Załuski i jezuici, „Roczniki Teologiczno-Kanoniczne" 1984, t. 31, z. 4, s. 55-70.

113 Jego spowiednikami byli Andrzej Sikorski (1659-1662) i Władysław Gurowski (1664-1673). Encyklopedia wiedzy o jezuitach..., s. 618, 203.

${ }^{114} \mathrm{Na}$ dworze ówczesnego biskupa chełmińskiego działał Adam Grabowski (1664-1667). Ibidem, s. 192.

${ }^{115}$ W roku szkolnym 1708/1709 teologami Załuskiego byli Jerzy Schrotter i Adam Rostkowski. Ibidem, s. 577. 


\section{Wiek i kariera kapelanów nadwornych}

Ze względu na znaczenie społeczne i polityczne osób, z którymi kapelani mieli okazję nawiązać kontakty podczas pełnienia służby dworskiej, ta forma aktywności mogła wywierać znaczny wpływ na dalszy przebieg kariery zakonników. Celem poniższych rozważań jest właśnie analiza tego zjawiska, które w ogólnych rysach można scharakteryzować $\mathrm{w}$ oparciu o narzędzia analizy statystycznej. W kręgu zainteresowania znajdują się przede wszystkim trzy aspekty: wiek w momencie przyjęcia stanowiska kapelana nadwornego, czas sprawowania tej funkcji oraz ewentualne piastowanie po jej złożeniu urzędów kierowniczych, na poziomie zarówno lokalnym, jak i zarządu prowincji. Tak sformułowany kwestionariusz badawczy nakłania do pominięcia braci zakonnych występujących w roli pomocników misjonarzy dworskich. Przebieg ich kariery różnił się od księży nie tylko $\mathrm{z}$ powodu wstępowania do zakonu w późniejszym wieku, ale również z braku formacji teologicznej i niemożności przyjęcia święceń kapłańskich ${ }^{116}$. Na mocy prawodawstwa zakonnego wspomniane cechy, właściwe dla całej grupy koadiutorów świeckich, uniemożliwiały awans na stanowiska kierownicze. Pozostaje więc 266-osobowa grupa księży, którzy zostali przyjęci na służbę dworską w latach 1608-1773. Tak długi okres można podzielić na trzy części. Pozwoli to uchwycić zarówno elementy stałe, jak i zmiany w strukturze badanej grupy. Pierwszy podokres, od utworzenia prowincji litewskiej do końca panowania Wazów na tronie polskim, cechował się silnym jeszcze zaangażowaniem jezuitów w życie dworu królewskiego, przy równoczesnym wzroście liczby zakonników pracujących w kręgu magnatów. W drugim, przypadającym na rządy królów-rodaków i Augusta II, liczba kapelanów nadwornych utrzymywała się na dość niskim poziomie. Na początku ostatniego podokresu, po wstąpieniu Augusta III na tron, zaznaczyła się tendencja wzrostowa, która po kilku latach uległa osłabieniu.

Gdy bierze się pod uwagę wiek kapelanów w momencie przyjęcia na służbę dworską, można zauważyć, że były to przeważnie osoby w pełni sił życiowych. Ich średni wiek wynosił 41,5 lat. W tabeli 1 widać, że niemalże połowa spowiedników i kaznodziejów nadwornych była pomiędzy 31. a 40. rokiem życia. Z kolei zakonnicy po czterdziestce stanowili zaledwie nieco ponad trzecią część wszystkich kapelanów. Osoby po pięćdziesiątce, także z racji ograniczonej wówczas długości życia, to nieco ponad $10 \%$ wszystkich duszpasterzy dworskich. Najmniejsza grupa składała się z osób mających mniej niż 30 lat. Fakt ten pozwala stwierdzić, że misjonarzami dworskimi stawały się osoby krótko po ukończeniu formacji zakonnej, która w kręgu jezuitów trwała aż do 30. roku życia. Mimo tego posiadały one już wystarczające doświadczenie $\mathrm{w}$ pracy duszpasterskiej. W badanym okresie

116 Ibidem, s. 286-287. Zob. też: E. Olivares, Los coadjutores, espirituales y temporales, de la Compañía de Jesús. Su origen y sus votos, „Archivum Historicum Societatis Iesu”, R. 33, 1964, nr 65, s. $102-121$. 
doszło jednak do poważnych zmian. Zaznaczyła się bowiem, zwłaszcza w połowie XVIII w., tendencja do zaniżania wieku w chwili objęcia stanowiska. Średni wiek wynosił 44,5 w pierwszym okresie, 43 - w drugim, a 38 lat - w trzecim. Innymi słowy, na dwory przysyłano coraz częściej młodszych zakonników. Zjawisko to wiązało się z praktyką mianowania prywatnych nauczycieli dla młodych magnatów. Przy wyborze takich osób kierowano się nieco innymi względami niż w przypadku spowiedników i kaznodziejów. Liczyło się bowiem nie doświadczenie duszpasterskie, lecz dydaktyczne, które jezuici zdobywali już w okresie formacji zakonnej, ucząc młodzież świecką przedmiotów retoryczno-humanistycznych. Dbano również o to, aby różnica wieku między wychowawcą a wychowankiem nie była zbyt duża.

Tabela 1. Wiek jezuickich kapelanów nadwornych i nauczycieli prywatnych prowincji litewskiej w momencie objęcia urzędu*

\begin{tabular}{|c|c|c|c|c|c|c|c|c|}
\hline & \multicolumn{8}{|c|}{ Lata } \\
\hline & \multicolumn{2}{|c|}{$1608-1773$} & \multicolumn{2}{|c|}{$1608-1668$} & \multicolumn{2}{|c|}{$1669-1733$} & \multicolumn{2}{|c|}{$1734-1773$} \\
\hline & $\mathbf{L}$ & $\%$ & $\mathbf{L}$ & $\%$ & $\mathbf{L}$ & $\%$ & $\mathbf{L}$ & $\%$ \\
\hline Do 30 & 9 & 3,4 & 0 & 0 & 0 & 0 & 9 & 8,7 \\
\hline Od 31 do 35 & 54 & 20,3 & 5 & 6,1 & 18 & 22,5 & 31 & 29,8 \\
\hline Od 36 do 40 & 73 & 27,4 & 21 & 25,6 & 19 & 23,7 & 33 & 31,7 \\
\hline Od 41 do 45 & 61 & 22,9 & 25 & 30,4 & 18 & 22,5 & 18 & 17,3 \\
\hline Od 46 do 50 & 36 & 13,5 & 15 & 18,3 & 11 & 13,8 & 10 & 9,6 \\
\hline Od 51 do 55 & 13 & 4,9 & 8 & 9,8 & 5 & 6,3 & 0 & 0 \\
\hline Ponad 56 & 20 & 7,6 & 8 & 9,8 & 9 & 11,2 & 3 & 2,9 \\
\hline Ogólnie & 266 & 100 & 82 & 100 & 80 & 100 & 104 & 100 \\
\hline
\end{tabular}

* Dane zostały obliczone poprzez odejmowanie roku urodzenia danego zakonnika od roku w momencie jego powołania na stanowisko kapelana lub nauczyciela domowego. Informacje pierwszego typu pochodzą z Encyklopedii wiedzy o jezuitach na ziemiach Polski i Litwy 1564-1995, drugie zaś - z katalogów rocznych (ARSI, Lituania, nr 6, 56-60).

Czas piastowania stanowiska kapelana nadwornego stanowił istotny element, sprzyjający pogłębianiu relacji $\mathrm{z}$ protektorem. W tej materii prawodawstwo zakonne nie udzielało jednoznacznych wskazówek. Kwestia przebywania poza klasztorem nie oznaczała bowiem tego samego co okres sprawowania urzędu. $\mathrm{W}$ porównaniu $\mathrm{z}$ innymi urzędami, jak rektora i prowincjała, których kadencja była ograniczona zgodnie z przepisami na okres trzyletni ${ }^{117}$, władze zakonne

117 Zasadę tę wprowadzono podczas piątej kongregacji generalnej w 1593 r. na żądanie papieża Klemensa VIII. Institutum..., t. 1, s. 562. 
zachowywały elastyczność w ustaleniu czasu przebywania na dworze. Jeśli relacje między kapelanem a magnatem układały się dobrze i nie naruszały podstawowych zasad funkcjonowania zakonu, uznawano, że lepiej zostawić księdza na dworze, niż go zmienić. Pomimo otwartości na oczekiwania przedstawicieli elit, okres piastowania urzędu kapelana był zazwyczaj dość krótki, gdyż wynosił średnio 5,3 lat. Jak ukazuje tabela 2 , prawie $2 / 3$ kapelanów przebywało na dworach przez okres krótszy niż pięcioletni. Połowa $\mathrm{z}$ nich miała pobyt zaledwie roczny. Z kolei dłuższe okresy piastowania funkcji spowiednika lub kaznodziei dworskiego należały do rzadkości. Gdy bierze się pod uwagę osobno każdy z trzech podokresów, można zauważyć tendencję do ograniczania długości pobytów. O ile w epoce Wazów trwały one średnio 6,7 lat, o tyle później spadły na poziom 5,2, a potem 4,2 lat.

Tabela 2. Czas sprawowania urzędu kapelana nadwornego i nauczyciela prywatnego*

\begin{tabular}{lcc}
\hline & L & $\%$ \\
\hline Od 1 do 5 lat & 176 & 66,2 \\
\hline Od 6 do 10 lat & 58 & 21,8 \\
\hline Od 11 do 15 lat & 15 & 5,6 \\
\hline Od 16 do 20 lat & 8 & 3,0 \\
\hline Ponad 20 lat & 9 & 3,4 \\
\hline Ogólnie & 266 & 100 \\
\hline
\end{tabular}

* ARSI, Lituania, nr 6, 56-60.

Zważywszy na przytoczone dotąd dane statystyczne, można stwierdzić, że pomimo obniżania się średniego wieku kapelanów, w chwili przyjęcia na służbę dworską nie dochodziło zazwyczaj do wydłużenia okresu tejże służby. Wręcz przeciwnie, zaznaczyła się odwrotna tendencja. Na tle tych przemian można zauważyć, że w fundamentalny sposób zmieniło się znaczenie urzędu kapelana nadwornego w ramach kariery zakonnej. O ile pierwotnie mógł on stanowić w pewnym stopniu formę wynagrodzenia za przeszłe zasługi położone na polu duszpasterskim (świadczy o tym dobitnie przejście misjonarzy obozowych do służby dworskiej), o tyle później obecność w otoczeniu magnatów stawała się coraz bardziej odskocznią do dalszych, bardziej prestiżowych urzędów zakonnych.

Ze względu na swoistego rodzaju specjalizację, której służba dworska wymagała od jezuitów, warto zastanowić się nad pytaniem, czy kapelani byli związani przeważnie z jednym dworem, czy też po ukończeniu pracy na nim angażowali się w życie innych dworów. O przejściu z otoczenia jednego dostojnika do kolejnego decydowały przede wszystkim koligacje między nimi, o czym jeszcze będzie mowa w części poświęconej mechanizmom nominacji. Na razie wystarczy odnotować, 
że prowadzenie duszpasterstwa na więcej niż jednym dworze stanowiło zjawisko stosunkowo rzadkie, występujące jedynie w przypadku 35 kapelanów. Z biegiem czasu stawało się ono coraz bardziej wyjątkowe. Podczas gdy w XVII stuleciu dawny spowiednik Sapiehów mógł przejść na służbę do ich rywali Paców ${ }^{118}$, w kolejnym stuleciu do tego typu wymiany już nie dochodziło. Zachowane źródła nie pozwalają wytłumaczyć przyczyny tej zmiany. Na tle wzrostu napięć pomiędzy fakcjami magnackimi przysyłanie na dwór kapelana, który uprzednio był związany z inną rodziną i który dlatego mógł mieć wobec niej dług wdzięczności, prawdopodobnie uważano za nierozsądne posunięcie ze strony władzy zakonnej. Należy też zauważyć odrębność grona jezuitów skupionego wokół dworu królewskiego w stosunku do dworów magnackich. Fakt ten wynikał m.in. ze struktury misji królewskiej, w której skład wchodziło wielu jezuitów obcego pochodzenia, zależnie od narodowości królowych ${ }^{119}$. Wymiana kapelanów nadwornych między dostojnikami państwowymi a rodziną panującą zdarzała się stosunkowo rzadko, a jeśli tak, to tylko w przypadku magnatów należących do stronnictwa prokrólewskiego ${ }^{120}$.

Przez cały badany okres nie brakowało oczywiście jezuitów, którzy spędzili większą część swego życia w zakonie w otoczeniu królów lub magnatów, przechodząc po śmierci dotychczasowego protektora na służbę jego następcy. Na tle powszechnej praktyki przypadki te stanowiły jednak wyjątek. Dwór królewski cechował się pod tym względem większą stabilnością niż dwory biskupie i magnackie. Ograniczając uwagę do tych ostatnich, warto tu przytoczyć kilka przykładów. Najdłużej na dworze przebywał Tomasz Krycki, związany z Czartoryskimi przez 37 lat, od 1708 r. do śmierci, która nastąpiła w 1745 r. ${ }^{121}$ Andrzej Narewicz spędził ponad 25 lat (1700-1711, 1716-1731) w kręgu Michała Serwacego Wiśniowieckiego. Podobnie wieloletnią służbę pełnił Tomasz Jurgiewicz najpierw w kręgu Lwa Sapiehy, a potem jego syna Kazimierza Leona. Wielu jezuitów związało swe losy z Radziwiłłami. W tej grupie wyróżniał się Mikołaj Kuczewski, który w latach 1742-1750 kierował edukacją synów „Rybeńki”: Janusza Tadeusza i Karola Stanisława Radziwiłłów, aby następnie zostać spowiednikiem i doradcą hetmana, a potem jego syna „Panie Kochanku”. Z kręgiem nieświeskim był związany również Michał Woronicz, od 1754 r. do kasaty Towarzystwa kapelan nadworny Karola Stanisława „Panie Kochanku”.

118 Taką karierę robił Stanisław Tupik, który służył po kolei u Pawła Jana Sapiehy (1658-1666) i u Mikołaja Stefana Paca (1674-1679). Encyklopedia wiedzy o jezuitach..., s. 703.

119 Byli to Austriacy lub Francuzi. S. Obirek, Jezuici na dworach Batorego i Wazów..., s. 39-45, 67-69, 82-84.

${ }^{120}$ Po ukończeniu służby na dworze Albrychta Stanisława Radziwiłła (1626-1634) Szymon Berent został spowiednikiem królewicza Aleksandra Karola. Paweł Wierzbicki, były kapelan księcia kanclerza, krótko przed śmiercią pełnił funkcję spowiednika Władysława Wazy. Ibidem, s. $51,735$.

${ }^{121}$ Działalność rozpoczął na dworze Kazimierza, zajmując się m.in. wychowaniem jego dzieci: Michała Fryderyka, Teodora Kazimierza i Augusta Aleksandra. ARSI, Lituania, nr 64, f. 388. 
Tezę o tymczasowym charakterze urzędu misjonarza dworskiego można zweryfikować, gdy uwzględni się liczbę kapelanów, którzy po opuszczeniu dworu otrzymali urzędy kierownicze. Jeżeli wykluczamy tych zakonników, którzy zmarli podczas sprawowania urzędu kapelana nadwornego (41 osób), to prawie połowa tych, którzy złożyli to stanowisko, została przełożonymi lokalnymi (102 z 225 osób, czyli 45\%). Zjawiskiem charakterystycznym było powierzanie tego typu stanowisk w obrębie placówek wspieranych przez dotychczasowych chlebodawców kapelanów. Na przykład Jan Poszakowski po opuszczeniu dworu kanclerzyny wdowy Anny Katarzyny z Sanguszków Radziwiłłowej, gdzie zajmował się m.in. wychowaniem jej najmłodszego syna Hieronima Floriana, został rektorem w Słucku (1735-1739), a potem w Nieświeżu (1739-1742) ${ }^{122}$. O ile to drugie kolegium zostało ufundowane właśnie przez Radziwiłłów, o tyle placówka słucka znalazła się w sferze wpływów wspomnianych magnatów ze względu na objęcie w posiadanie przez nich tzw. dóbr neuburskich ${ }^{123}$. Inny interesujący przykład dostarcza Józef Powilewicz, w latach 1750-1758 prywatny nauczyciel synów Jozafata Zyberka, właściciela Iłłukszty ${ }^{124}$. Gdy w 1762 r. miejscowa rezydencja została podniesiona do rangi kolegium, Powilewicza, naówczas wykładającego filozofię w Akademii Wileńskiej, sprowadzono z powrotem do Iłłukszty w celu objęcia stanowiska rektora ${ }^{125}$.

Podczas gdy urzędy kierownicze na poziomie lokalnym stanowiły osiągnięcie możliwe dla stosunkowo szerokiego grona księży, udział w zarządzie prowincji okazywał się rzadszą formą aktywności wśród byłych kapelanów nadwornych. Niemniej jednak z 225 jezuitów, którzy zdążyli odejść ze służby dworskiej, ok. 10\% objęło stanowiska prowincjała lub jego sekretarza (viceprovincialis) oraz prokuratora prowincji. Wspomniany odsetek byłby o wiele wyższy, gdyby doliczono doradców przełożonego prowincji (consultores patris provincialis), odbywających z nim regularne spotkania, a także informujących kurię generalną o stanie poszczególnych placówek ${ }^{126}$. Stosunkowo łatwy dostęp do urzędu prowincjała mieli jezuici uprzednio związani z dworem królewskim. Tak było w przypadku Grzegorza Schönhoffa, który znalazł się na czele prowincji litewskiej w latach 1658-1662 $2^{127}$. Ze względu na trwające nadal kontakty $\mathrm{z}$ dworem Wazów nie zawsze byli kapelani nadworni mogli osobiście kierować prowincją. Tak działo się podczas kadencji Wojciecha Cieciszewskiego, który za zgodą generała powierzył zawiadywanie bieżącymi sprawami swemu sekretarzowi ${ }^{128}$. W XVIII w. stanowisko prowincjała

\footnotetext{
122 B. Natoński, Poszakowski Jan Antoni (1684-1757), PSB, t. 27, Wrocław 1982-1983, s. 705.

${ }^{123}$ J. Lesiński, Spory o dobra neuburskie, „Miscellanea Historico-Archivistica” 1996, t. 6, s. 127-128.

124 Zob. G. Manteuffel, O starodawnej szlachcie krzyżacko-rycerskiej na kresach inflanckich, Lwów 1910, s. 49.

${ }^{125}$ Fontes Historiae Latviae..., t. 1, Rīga 1940, s. 182.

${ }^{126}$ Encyklopedia wiedzy o jezuitach..., s. 301; M. Friedrich, Der lange Arm..., s. 225-226.

${ }^{127}$ L. Grzebień, Schönhoff Grzegorz (1596-1667), PSB, t. 35, s. 620-622.

${ }^{128}$ S. Obirek, Jezuici na dworach Batorego i Wazów..., s. 76.
} 
osiągnęli zakonnicy uprzednio związani z dworami magnackimi i biskupimi. Do takich przypadków można zaliczyć awans Kazimierza Brzozowskiego, który po ukończeniu służby w kręgu Michała Serwacego Wiśniowieckiego pełnił urząd rektora $\mathrm{w}$ wielu domach, a także stanął na czele prowincji ${ }^{129}$. Podobną ścieżką dążył Jan Juraha, długoletni spowiednik biskupa wileńskiego Michała Jana Zienkowicza ${ }^{130}$.

Kontakty nawiązane przez misjonarzy dworskich były przydatne na stanowisku prokuratora prowincji, którego zadanie polegało na reprezentowaniu zakonu wobec świata zewnętrznego, a także na prowadzeniu korespondencji z kurią generalną ze względu na częste podróże prowincjała. W związku z tym rezydował on na stałe $\mathrm{w}$ Warszawie. W przeciwieństwie do stanowisk prowincjała i rektora, w których przypadku nominacje były udzielane przez generała, urząd prokuratora prowincji miał charakter elekcyjny ${ }^{131}$. Jego wybór, dokonywany przez obradującą co trzy lata kongregację prowincjalną, odzwierciedlał w dużym stopniu preferencje uczestników. W XVIII stuleciu stanowisko prokuratora otrzymało kilku jezuitów uprzednio związanych z Radziwiłłami: Kazimierz Juraha, brat wspomnianego już Jana, Kazimierz Stankiewicz oraz Stanisław Klonowski. Aktywność pierwszego na rzecz Anny Katarzyny z Sanguszków podczas kadencji prokuratora została dobrze udokumentowana $\mathrm{w}$ świetle korespondencji ${ }^{132}$. Jezuita nie był biernym obserwatorem wydarzeń politycznych rozgrywających się w stolicy, lecz aktywnie pośredniczył w relacjach między kanclerzyną a dworem królewskim, wykorzystując własne kontakty ze spowiednikami Augusta III. Angażował się nawet - choć bezskutecznie - w pozyskiwanie wakansów dla syna chlebodawczyni.

Mimo tak intensywnego zaangażowania w krąg elity Wielkiego Księstwa Litewskiego, rzadko dochodziło do dymisji kapelanów nadwornych z Towarzystwa. Przyczynę wystąpień stanowiła zazwyczaj decyzja o wynagradzaniu kapelanów nadwornych beneficjami kościelnymi, których przyjęcie było zakazane przez Konstytucje. Takich przykładów nie brakowało wśród spowiedników królewskich ani w krajach zachodnioeuropejskich, ani w Rzeczypospolitej, o czym świadczy przypadek Stanisława Pstrokońskiego, spowiednika Władysława IV ${ }^{133}$. Brak dymisji wśród jezuitów związanych $\mathrm{z}$ dostojnikami państwowymi można tłumaczyć nie tylko przywiązaniem do Towarzystwa, ale też słabszą pozycją dworów magnackich. $\mathrm{W}$ porównaniu $\mathrm{z}$ władcami możnowładcy posiadali słabsze atuty przy próbach związania jezuitów z własną osobą, gdyż nie dysponowali na tyle intratnymi prebendami, jak królowie. Ponadto władza zakonna mogła skuteczniej

\footnotetext{
${ }^{129}$ Encyklopedia wiedzy o jezuitach..., s. 73.

130 Ibidem, s. 255.

${ }^{131}$ Ibidem, s. 540.

${ }^{132}$ Archiwum Główne Akt Dawnych [dalej: AGAD], Archiwum Radziwiłłów [dalej: AR], dz. V, nr 6202/I-IV.

${ }^{133}$ P. Sczaniecki, Pstrokoński Stanisław (ok. 1591-1657), PSB, t. 29, Wrocław-Kraków 1986, s. 275277; S. Obirek, Jezuici na dworach Batorego i Wazów..., s. 60-62.
} 
oprzeć się presji magnatów, usuwając zakonnika, który poprzez ubieganie się o zaszczyty zachowywał się nielojalnie wobec zgromadzenia. Lawirowanie przez przełożonych zakonnych umożliwiała w końcu wielość dworów, z którą wiązało się istnienie rozproszonej władzy. Pomimo opisanej sytuacji dochodziło w praktyce do nominacji kapelanów będących jeszcze przed złożeniem uroczystych ślubów zakonnych ${ }^{134}$. Ponieważ te znacznie utrudniały wystąpienie z Towarzystwa, decyzję władz zakonnych można uznać $\mathrm{w}$ takich przypadkach za próbę pozostawienia otwartej furtki młodym księżom, aby jeszcze mieli szansę na zmianę wyboru drogi życiowej.

\section{Nominacje kapelanów nadwornych}

Podczas gdy źródła zakonne pozwalają dość dokładnie obliczyć liczbę kapelanów nadwornych, ich wiek oraz okres sprawowania urzędu, zajmowanie się pytaniami, jakie kryteria decydowały o mianowaniu danej osoby na to stanowisko i którą drogą wprowadzano w życie tę nominację, wymaga od badacza sięgania po materiały o charakterze fragmentarycznym, jak korespondencja i dzienniki magnatów. Podejmując najpierw kwestię tych cech, które czyniły jezuitów pożądanymi kandydatami do służby dworskiej, można stwierdzić, że na to wpływało wiele czynników, wśród których najważniejsze były - jak już wspomniano - rozległa kultura osobista i obycie towarzyskie oraz rozeznanie $w$ tzw. kazusach sumienia. Takie argumenty przemawiały nawet do magnatów, którzy prowadzili szeroko zakrojoną działalność fundatorską na rzecz innych zgromadzeń zakonnych ${ }^{135}$. Jednakże konstatacja ta jeszcze nie tłumaczy wyboru tylko niektórych spośród jezuitów. Próbując odpowiedzieć na powyższe pytania, warto skupić się na aspektach, które zróżnicowały personel jezuicki. Są to m.in. proweniencja geograficzna, pochodzenie społeczne i zależności rodzinne, świadczące o orientacji w środowisku, w którego ramach kapelani mieli prowadzić duszpasterstwo, oraz cechy charakteru i umiejętności językowe, które decydowały o ich zdolności do wykonywania zadań.

Jedyny aspekt, który można zbadać za pomocą narzędzi analizy statystycznej, stanowi proweniencja geograficzna kapelanów nadwornych. Struktura tej grupy

${ }^{134}$ Spośród kapelanów „Rybeńki” zarówno Feliks Wierzbicki, jak i Mikołaj Kuczewski złożyli wyższe śluby, gdy już przebywali na dworze radziwiłłowskim. Diariusz Michała Kazimierza Radziwiłła [1702] 1719-1761 - kopia, AGAD, AR, dz. VI, nr II-80a, s. 474; ARSI, Lituania, nr 3, s. 48-49.

${ }^{135} \mathrm{Na}$ przykład dobroczyńca pijarów Jan Scipio del Campo, marszałek nadworny litewski, miał jako kapelana nadwornego jezuitę Sebastiana Litarowicza $\mathrm{z}$ prowincji polskiej. Kazimierz Juraha do Anny Katarzyny Radziwiłłowej, Polkow pod Warszawą, 13 VIII 1739, AGAD, AR, dz. V, nr 6202/I. Na temat relacji Scipiona del Campo z pijarami zob.: A. Rachuba, Scipio Jan (zm. 1738), PSB, t. 36, Warszawa-Kraków 1995-1996, s. 78-80; J. Kurkowski, Z dziejów polskiego edytorstwa źródeł historycznych: Maciej Dogiel (1715-1760), „Analecta. Studia i Materiały z Dziejów Nauki”, R. 15, 2006, z. 1-2, s. 96. 
pod względem regionu pochodzenia, przedstawiona w tabeli 3, odzwierciedla nie tylko ogólną kompozycję personelu prowincji litewskiej, ale też zmiany dokonujące się na przestrzeni badanego okresu. Na przykład w miarę zmniejszania się odsetka cudzoziemców wśród jezuitów prowincji litewskiej, coraz rzadziej dochodziło do ich nominacji na stanowisko kapelana nadwornego. Podobnej tendencji ulegała grupa Mazowszan. Zwiększył się natomiast udział zakonników urodzonych na ziemiach ruskich państwa polsko-litewskiego, określanych jako rutheni. Kapelanów nadwornych na tle całego personelu prowincji wyróżniało silne zaangażowanie zakonników urodzonych na terenie Warmii i Prus, zazwyczaj dobrze znających język niemiecki. Przypuszczać można, że ze względu na obecność licznych cudzoziemców na dworach i w milicjach magnackich posługa duszpasterska jezuitów władających tym językiem była szczególnie pożądana.

Tabela 3. Proweniencja geograficzna jezuickich kapelanów nadwornych i prywatnych nauczycieli prowincji litewskiej*

\begin{tabular}{|c|c|c|c|c|c|c|c|c|}
\hline & \multicolumn{8}{|c|}{ Lata } \\
\hline & \multicolumn{2}{|c|}{$1608-1773$} & \multicolumn{2}{|c|}{$1608-1668$} & \multicolumn{2}{|c|}{$1669-1733$} & \multicolumn{2}{|c|}{$1734-1773$} \\
\hline & $\mathbf{L}$ & $\%$ & $\mathbf{L}$ & $\%$ & $\mathbf{L}$ & $\%$ & $\mathbf{L}$ & $\%$ \\
\hline Lituanus & 56 & 21,1 & 17 & 20,7 & 16 & 20,0 & 23 & 22,1 \\
\hline Livo & 4 & 1,5 & 2 & 2,4 & 0 & 0 & 2 & 1,9 \\
\hline Masovita & 60 & 22,6 & 23 & 28,0 & 20 & 25,0 & 17 & 16,3 \\
\hline Polonus & 15 & 5,6 & 10 & 12,2 & 4 & 5,0 & 1 & 1,0 \\
\hline Ruthenus & 48 & 18,0 & 9 & 11,0 & 11 & 13,8 & 28 & 26,9 \\
\hline Samogita & 15 & 5,6 & 3 & 3,7 & 6 & 7,7 & 6 & 5,8 \\
\hline Subsylvanus & 8 & 3,0 & 2 & 2,4 & 2 & 2,7 & 4 & 3,9 \\
\hline Varmiensis & 49 & 18,4 & 11 & 13,4 & 18 & 22,0 & 20 & 19,2 \\
\hline Obcokrajowiec & 11 & 4,2 & 5 & 6,2 & 3 & 3,8 & 3 & 2,9 \\
\hline Ogólnie & 266 & 100 & 82 & 100 & 80 & 100 & 104 & 100 \\
\hline
\end{tabular}

* Lista kapelanów i nauczycieli domowych, opracowana na podstawie katalogów rocznych (ARSI, Lituania, nr 6, 56-60), została uzupełniona o informacje na temat proweniencji zakonników, pochodzące z Encyklopedii wiedzy o jezuitach na ziemiach polski i Litwy 1564-1995.

Bardziej relewantne okazywało się pochodzenie społeczne potencjalnych kapelanów nadwornych. Pomimo faktu, że zasadniczy trzon personelu stanowili, zwłaszcza w XVIII w., przedstawiciele rodzin zamożnej szlachty, wśród jezuickich duszpasterzy dworskich pojawiały się często osoby o niższym pochodzeniu, 
wywodzące się z drobnej szlachty, a nawet z mieszczaństwa ${ }^{136}$. Kapelani urodzeni w znaczniejszych rodzinach zazwyczaj robili karierę w kręgu tych rodów, których wpływy polityczne skupiały się na innych terenach ${ }^{137}$. Stosunkowo niska pozycja społeczna kapelanów nadwornych decydowała o ich bezwzględnej lojalności, a także o łatwości usuwania osób niespełniających oczekiwań chlebodawców. Nie znajdując bowiem silniejszego oparcia wśród szlachty tworzącej lokalną elitę, jezuiccy misjonarze dworscy stawali się szczerze oddani magnatom, zawdzięczając ich protekcji ewentualne awanse w hierarchii Towarzystwa. Fakt ten był korzystny również dla przełożonych, którzy ostatecznie decydowali o rozdaniu urzędów zakonnych. W oparciu o dwory magnackie władze zakonne mogły powołać na wysokie stanowiska osoby, które miały - nieraz mimo wielkich zdolności - ograniczone szanse na awans.

Pomimo odległości, która dzieliła kapelana od swego protektora w zakresie możliwości i znaczenia społecznego, w niektórych przypadkach można zauważyć koligacje lub nawet pokrewieństwo. Na przykład Piotr Starczewski pracował w latach 1641-1644 na dworze swego brata Stanisława, sufragana płockiego ${ }^{138}$. Józef Siesicki, kapelan Anny Luizy z Mycielskich Radziwiłłowej, drugiej żony „Rybeńki”, był natomiast spokrewniony z Leonem Michałem Radziwiłłem, poprzednim mężem magnatki ${ }^{139}$. Opis zależności rodzinnych można by jeszcze poszerzyć, biorąc pod uwagę pokrewieństwo między kapelanami a wysokimi urzędnikami dworskimi. Na przykład Kazimierz Stankiewicz, spowiednik Anny Katarzyny z Sanguszków, był synem ochmistrzyni dworu kanclerzyny ${ }^{140}$.

Do cech, które bezpośrednio wpływały na zaangażowanie jezuitów w środowisko dworskie, należały osobowość i kompetencje językowe. W pierwszej kwestii pisano dość dużo tylko w przypadku spowiedników i kaznodziejów królewskich ${ }^{141}$. Oprócz opinii wystawianych przez ludzi dworskich, niekiedy pod

${ }^{136}$ Pochodzenie średnio- lub drobnoszlacheckie miało wielu kapelanów radziwiłłowskich, jak Jan Poszakowski, urodzony w powiecie upickim, oraz Mikołaj Kuczewski, z Podlasia. Zob.: B. Natoński, op. cit., s. 704; Encyklopedia wiedzy o jezuitach..., s. 532.

137 Wśród spowiedników kolejnych właścicieli Nieświeża na przykład Michał Suffczyński wywodził się z wpływowej rodziny z województwa lubelskiego. Brat Michała Woronicza, Nikodem piastował natomiast urząd kasztelana kijowskiego. K. Niesiecki, Herbarz polski Kaspra Niesieckiego S.J.: powiększony dodatkami z poźniejszych autorów, rękopismów, dowodów urzędowych, wyd. J.N. Bobrowicz, t. 8, Lipsk 1841, s. 560-561, t. 9, Lipsk 1842, s. 427-429.

${ }^{138}$ Encyklopedia wiedzy o jezuitach..., s. 643; T. Żebrowski, Starczewski Stanisław (ok. 1580-1643), PSB, t. 42, Warszawa-Kraków 2003-2004, s. 293.

${ }^{139}$ Compendium vitae p. Josephi Siesicki, Lietuvos Mokslų Akademijos Biblioteka [dalej: LMAB], BF 3192, k. 33. Marcjanna, matka Leona Michała, pochodziła z domu Siesickich. A. Rachuba, Siesicki (właściwie Dowmont Siesicki) Michał Kazimierz h. Bawoła Głowa (zm. 1713), PSB, t. 37, s. 371.

${ }^{140}$ Jan Poszakowski do Anny Katarzyny Radziwiłłowej, Nieśwież, 22 III 1741, AGAD, AR, dz. V, nr 12212.

${ }^{141}$ S. Obirek, Jezuici na dworach Batorego i Wazów..., passim. 
wpływem aktualnych wydarzeń, na uwagę zasługują także oceny pochodzące z kręgów zakonnych, wyrażane w katalogach trzyletnich. Niezwykle pochlebnie na temat wielokrotnie już wspomnianego Mikołaja Kuczewskiego wypowiadał się pamiętnikarz Marcin Matuszewicz, którego z jezuitą łączyły więzi przyjaźni od lat młodzieńczych. Podkreślał on przykładną modestię kapelana, która pozwoliła mu wejść do wąskiego grona doradców hetmana ${ }^{142}$. Pozytywną ocenę wystawili Kuczewskiemu również jego współbracia w roku po uzyskaniu stanowiska wychowawcy dzieci hetmańskich ${ }^{143}$.

Elementem zwiększającym skuteczność pracy duszpasterskiej kapelanów nadwornych była znajomość języków nowożytnych. Oprócz niemieckiego, o którym już wspomniano, szczególnego znaczenia nabrała francuszczyzna jako narzędzie komunikacji w życiu towarzyskim i naukowym elit. Do wzrostu zainteresowania tym językiem na terenie dawnej Rzeczypospolitej doszło już w XVII w. za przyczyną królowych pochodzenia francuskiego. Jednak dla tego okresu brak systematyczności w odnotowaniu w katalogach osobowych języków, jakimi władali zakonnicy, uniemożliwia ustalenie dokładnego poziomu znajomości języka francuskiego wśród jezuitów. Informacje na ten temat zaczęto dostarczać regularnie dopiero w połowie XVIII w. Sądzić należy, że kompetencje w zakresie gramatyki języka francuskiego należały wcześniej do rzadkości. Tradycyjnie starania o przyswojenie tego narzędzia komunikacji były pozostawiane dobrej woli zainteresowanych. Na przykład, według autora nekrologu, na początku XVIII w. Jozafat Sokołowski nauczył się języka francuskiego jako dorosły człowiek, podczas służby dworskiej, w celu słuchania spowiedzi ${ }^{144}$. Sytuacja zaczęła zmieniać się dopiero od lat 30. tego stulecia, w miarę wprowadzania do programu szkolnego kursów języków nowożytnych. Na terenie prowincji litewskiej inicjatywy te sprawiły, że po kilku latach kandydaci do zakonu już posiadali choć podstawową znajomość języka francuskiego. O rozpowszechnieniu się tej wiedzy wśród personelu prowincji litewskiej, jeszcze przed przybyciem zakonników wypędzonych z Francji w 1762 r., dobitnie świadczy fakt, że w latach 50. nie tylko jezuici pracujący w kolegiach szlacheckich, ale też ci zaangażowani jako wychowawcy na dworach magnackich wyróżniali się znajomością tego języka ${ }^{145}$. Niezależnie od motywacji, wielokrotnie

${ }^{142}$ M. Matuszewicz, Diariusz życia mego, oprac. B. Królikowski, Z. Zielińska, t. 2, Warszawa 1986, s. 353.

143 „Est ingenii et iudici boni. Prudentiae et experientiae bonae. Profectus in literis boni. Complexionis sanguineo-melancholicae. Valet ad humaniora et concionandum". ARSI, Lituania, nr 26, f. $243 \mathrm{v}$.

144 Ibidem, nr 65, s. 205.

${ }^{145}$ Byli to: Jakub Jacewicz wychowujący dzieci Wilhelma Henryka Lievena, Józef Powilewicz pracujący jako nauczyciel na dworze Jozafata Zyberka, Rafał Hempel związany z kręgiem Konstantego Ludwika Platera, Kazimierz Hołówka zatrudniony jako pedagog przez Antoniego Tadeusza Przeździeckiego oraz Karol Wyrwicz nadzorujący edukację Józefa Hylzena. Ibidem, nr 32, passim. 
zakonnicy posiadający podstawowe umiejętności wykorzystywali pobyt w kręgu magnatów dla doszlifowania kompetencji językowych. Tak czynił Jan Poszakowski, który w podeszłym wieku tłumaczył kazania francuskich autorów. W ostatnim roku życia (1756/1757) został ponadto powołany na stanowisko profesora języka francuskiego i historii w kolegium nieświeskim ${ }^{146}$. Język ten przyswoił sobie również Mikołaj Kuczewski, o 20 lat młodszy. Opanowawszy język francuski już podczas studiów filozoficznych w Wilnie, w kolejnych latach doskonalił zdobyte umiejętności: korespondował ze swą chlebodawczynią hetmanową Franciszką Urszulą z Wiśniowieckich, uczył gramatyki swoich podopiecznych i dokonywał tłumaczeń na język polski.

Kapelana nadwornego wyznaczano na prośbę zainteresowanego, który zazwyczaj wskazywał na konkretną, znaną już wcześniej osobę. Mimo że nominacji dokonywał prowincjał, ubiegano się o zgodę generała, który ostatecznie zalecał prowincjałowi wykonanie podjętej decyzji ${ }^{147}$. Takie rozwiązanie nie było jednak powszechnie akceptowane. Przełożeni prowincji z niepokojem patrzyli na ingerencję $\mathrm{w}$ politykę personalną zakonu ze strony możnowładców, co właśnie umożliwiała tradycyjna procedura wyznaczania kapelana nadwornego ${ }^{148}$. Rzeczywiście opisany sposób obsadzania urzędu kapelana nadwornego zwiększał wpływy zamożnych protektorów na średni szczebel administracji zakonu, pozostawiając generała w wygodnej pozycji nadzorcy i gwaranta postanowień prowincjała. $\mathrm{O}$ ile pierwszy zachowywał pewien dystans i swobodę, o tyle w listach przełożonych prowincji odczuwalna jest - w warstwie słownej - uległość wobec rozkazów dobroczyńców ${ }^{149}$. Inny charakterystyczny mechanizm stanowiło swoistego rodzaju dziedziczenie kapelanów wskutek przejęcia istniejących już wcześniej dworów. Tak działo się w przypadku pierwszego misjonarza dworskiego Wiśniowieckich, Kazimierza Puciłowskiego, który dotychczas służył w kręgu marszałka wielkiego litewskiego Jana Karola Dolskiego. Gdy Michał Serwacy poślubił Katarzynę, córkę zmarłego, jezuita wszedł w krąg Wiśniowieckich ${ }^{150}$. Podobna sytuacja nadarzyła

${ }^{146}$ J. Lambert, Kazania na niedziele całego roku święta, nauki wielce do zbawienia potrzebne zawierające, $z$ francuskiego na polski język przełożone przez ks. J. Poszakowskiego, cz. 1-2, Wilno 1752.

${ }^{147}$ Zjawisko to znajduje odzwierciedlenie w brulionach listów generała, skierowanych bezpośrednio do magnatów. Zob. ARSI, Germania, nr 116-117, passim.

${ }^{148} \mathrm{Na}$ przykład w 1573 i w 1581 r. prowincja górnoniemiecka domagała się, aby decyzja o wyznaczeniu kapelana nadwornego należała do kompetencji generała. Ani trzecia, ani czwarta kongregacja generalna nie ustosunkowała się jednak do tej prośby. W tej sytuacji powierzanie urzędu kapelana nadwornego nadal pozostawało kwestią do uzgodnienia między petentem a prowincjałem. Zob. R. Bireley, The Jesuits and the Thirty Years War..., s. 28.

149 Odpowiadając na prośbę „Rybeńki”, Wojciech Bohuszewicz proponował Feliksa Wierzbickiego, „dobrze znajomego" księciu, prosząc o jego zgodę. Wojciech Bohuszewicz do Michała Kazimierza Radziwiłła, Wilno, 3 V 1730, AGAD, AR, dz. V, nr 1067.

${ }^{150}$ I. Czamańska, Wiśniowieccy. Monografia rodu, Poznań 2007, s. 436. 
się po ślubie Salomei Anny z Sapiehów $2^{\circ}$ v. Nowosielskiej z Jerzym Radziwiłłem. Wraz z parą osiadł w Lubczu Florian Kościesza, pełniący wcześniej posługę na dworze Leona Nowosielskiego ${ }^{151}$.

Na drodze urzeczywistnienia nominacji stawały niekiedy przeszkody. Trudności pojawiły się w przypadku powołania Jozafata Sokołowskiego na urząd kapelana Mikołaja Faustyna. Z taką prośbą wystąpił magnat już w 1709 r. ${ }^{152}$ Generał Michelangelo Tamburini odmówił, twierdząc, że pożądana osoba jeszcze nie złożyła uroczystych ślubów ${ }^{153}$. Dopiero w 1714 r. prośba księcia doczekała się realizacji. $\mathrm{W}$ innych przypadkach władza zakonna wprost odmawiała. Tak było w przypadku wyznaczenia Kazimierza Brzozowskiego, naówczas kaznodziei w Warszawie, na wychowawcę „Rybeńki” w 1717 r. ${ }^{154}$ Prestiżowego urzędu zakonnego w stolicy nie chciano zamienić na inny, niewątpliwie też zaszczytny, ale przynoszący mniej pożytku pod względem duszpasterskim. W tym wypadku zasługuje także na uwage fakt, że Anna Katarzyna bezskutecznie próbowała ominąć prowincjała, wyprawiając Pawła Bohomolca do Warszawy, żeby uzyskać od miejscowego rektora nominację osoby pożądanej przez Radziwiłłów ${ }^{155}$.

Za otrzymany urząd jezuici dziękowali pełnymi emfazy listami, wyrażając gotowość pełnienia wiernej służby. Jednakże z przybyciem na dwór niekiedy zwlekano. O kilka miesięcy opóźniał się wyjazd Kazimierza Jurahy: powołany w kwietniu 1736 r. na służbę u Anny Katarzyny z Sanguszków, na początku września przebywał nadal w Warszawie, obiecując, że wyruszy ze stolicy po św. Mateuszu (21 IX) lub po św. Michale (29 IX). Tak wielką zwłokę tłumaczył Radziwiłłowi obowiązkami związanymi z urzędem prokuratora prowincji i złym samopoczuciem $^{156}$. Oprócz podziękowań Juraha wyrażał również niepokój związany z charakterem służby, wynikający z braku przyzwyczajenia do życia dworskiego oraz ze słabości zdrowia ${ }^{157}$.

${ }^{151}$ H. Dymnicka-Wołoszyńska, Radziwiłł Jerzy h. Trąby (1721-1754), PSB, t. 30, Kraków-Wrocław 1987, s. 238. O aktywności Kościeszy na dworze Radziwiłła pisano w nekrologu. ARSI, Lituania, nr 64, s. 337.

152 Michelangelo Tamburino do Mikołaja Faustyna Radziwiłła, do Zdzięcioła, 7 XII 1709, ARSI, Germania, nr 116, s. 724. Sokołowski był wówczas misjonarzem u Chreptowiczów w Szczorsach. Sokołowski Jozafat, w: Encyklopedia wiedzy o jezuitach..., s. 631.

${ }^{153} \mathrm{~W}$ lipcu 1710 r. generał prosił Radziwiłła, aby wybrał sobie kapelana. M. Tamburino do M.F. Radziwiłła, do Zdzięcioła, 26 VII 1710, ARSI, Germania, nr 116, s. 735. Korespondencja toczyła się nadal latem 1712 r. Tenże do tegoż, do Zdzięcioła, 2 VII 1712, ibidem, s. 807. Sokołowski złożył uroczyste śluby 15 listopada 1711 r. ARSI, Germania, nr 34, s. 336-337.

${ }^{154}$ AGAD, AR, dz. VI, nr II-80a, s. 6.

${ }^{155}$ Paweł Bohomolec do Anny Katarzyny Radziwiłłowej, Warszawa, 24 VII 1717, AGAD, AR, dz. V, nr 1047.

${ }^{156}$ Kazimierz Juraha do Hieronima Floriana Radziwiłła, Warszawa, 1 IX 1736, ibidem, nr 6202/I.

157 „Uznaję w tym partykularną ks. jegomości dobrodzieja mego ku mnie słudze i klientowi swemu przychylność, którą nade wszystko sobie poważam, i nieśmiertelną na wdzięcznym sercu 
$\mathrm{O}$ ile władze zakonne nie zawsze mogły spełnić oczekiwania magnatów w związku ze sprowadzeniem na dwór kapelana lub wychowawcy, o tyle w przypadku niezadowolenia protektora działania mające na celu usunięcie niepożądanego zakonnika były podejmowane natychmiast. Władza zakonna nie kwestionowała przy tym zasadności postawionych zarzutów, lecz ulegała żądaniom, mimo trudności w znalezieniu zastępcy. W obronie swego dobrego imienia występował natomiast oskarżony, wystosowując - zazwyczaj bezskutecznie - listy do magnatów. Powodem oddalenia od służby dworskiej było niewykonanie rozkazów chlebodawcy, choć trudno ustalić dokładnie rodzaj przewinienia w danym przypadku. Na przykład podczas wojny o sukcesję polską Feliks Wierzbicki tłumaczył się „Rybeńce”, że nie poszedł do obozu dlatego, że nie było rozkazu i że powołanie zakonne nie pozwala mu zająć stanowiska wobec bieżących spraw politycznych. Jako dodatkowy pretekst przytaczał konieczność przebywania przy umierającej matce ${ }^{158}$. Mimo tych wyjaśnień zakonnik został szybko usunięty. W kwestii oddalenia nauczycieli wiele do powiedzenia mieli wychowankowie. Piętnastoletniemu „Rybeńce” wystarczyło powiedzieć matce, że nauczyciel Walenty Kamiński zaniedbał go i był człowiekiem mało inteligentnym, aby wymusić na nim dymisję ${ }^{159}$. Ofiarą podobnych zarzutów padł również inny zakonnik, Ignacy Petrycy, nadzorujący edukację ordynata kleckiego Józefa Mikołaja Radziwiłła, który po ubezwłasnowolnieniu ojca znalazł się pod kuratelą krewnego Hieronima Floriana ${ }^{160}$. Niechętny Towarzystwu książę sprowadził na miejsce Petrycego pijara Macieja Tukałłę. Wreszcie jezuici bywali także usuwani z powodu sporów o opiekę nad sierotami. Tak zdarzyło się Franciszkowi Judzowi zajmującemu się wychowaniem Aleksandra Michała Sapiehy, gdy po śmierci jego ojca Kazimiera Leona matka Karolina z Radziwiłłów poślubiła Józefa Aleksandra Jabłonowskiego, zapoczątkowując z braćmi zmarłego długoletni zatarg o kuratelę nad dziećmi z pierwszego małżeństwa ${ }^{161}$.

zapisując obligacyją. [...] Poważam się, [...] rzetelnie moją u tak wysokiego dworu reprezentować niesposobność: kiedy i humor mój nie do dworskiej wrodzonej maniery, i zdrowie osobliwe tego roku nadrujnowane, bardziej mię do prywatnego w zakonnej celi uspokojenia, niż do publicznego dysponują światła”. Tenże do tegoż, Warszawa, 14 IV 1736, ibidem.

${ }^{158}$ Feliks Wierzbicki do Michała Kazimierza Radziwiłła, Nieśwież, 29 X 1734, ibidem, nr 17327.

159 „Znowu do nauk jam się zaczął aplikować, ale jezuita który nie wymyślił prochu bardzo mnie opuścił, i źle traktował, aż musiałem się skarżyć matce mojej, która go zaraz odprawiła ode dworu, mnie z sobą do Nieświeża wzięła”. AGAD, AR, dz. VI, nr II-80a, s. 6.

${ }^{160}$ Ignacy Petrycy do nieznanego adresata, bez miejsca i daty, AGAD, AR, dz. V, nr 11551, s. 9-12.

${ }^{161}$ Franciszek Judz do Józefa Stanisława Sapiehy, Kock, 24 III 1741, LMAB, f. 139, nr 5340. 


\section{Życie kapelanów nadwornych}

Opisaniu życia codziennego i form aktywności jezuickich kapelanów nadwornych można by poświęcić wiele miejsca, na co jednak nie pozwala objętość niniejszego artykułu. Znaczenie tematu wymaga jednak choć zwięzłej charakterystyki. Podejmując to zagadnienie, należy podkreślić, że najmniej wiadomo o sposobie prowadzenia duszpasterstwa przez misjonarzy dworskich, mimo że było ono ich zasadniczym zadaniem. Nie zachowały się bowiem odpisy ani notatki ich wykładów duchowych. Można jedynie przypuścić, że była to znacząca aktywność przynosząca wymierne skutki, niekiedy nawet w postaci nawróceń osób z otoczenia magnata na katolicyzm ${ }^{162}$. Nieco lepiej zostały udokumentowane inne aspekty życia kapelanów, jak wybór miejsca zamieszkania i mobilność, zajęcia niezwiązane ściśle z powołaniem zakonnym i zainteresowania kulturalne, wstawiennictwo za osobami trzecimi oraz oczekiwania wobec protektorów. Tym właśnie zagadnieniom warto poświęcić kilka uwag.

Poważnym problemem był wybór miejsca zamieszkania jezuity w czasie świadczenia posługi duszpasterskiej na dworze. Jak wyżej wspomniano, prawodawstwo zakonne nakazywało, aby kapelan nadworny mieszkał razem ze współbraćmi. Podczas kiedy towarzyszył swemu protektorowi w podróży, powinien on nocować nie w pałacu lub w karczmie, lecz w klasztorze lub na plebanii, które znajdują się $\mathrm{w}$ miejscu postoju ${ }^{163}$. W nieprzestrzeganiu klauzury i ślubu ubóstwa władza zakonna upatrywała nie tylko poważnego wykroczenia przeciw dyscyplinie Towarzystwa, ale też potencjalnego zagrożenia dla jego spójności. Z tego powodu przełożeni starali się sprawować kontrolę nad mobilnością kapelanów nadwornych. Temu służył wspomniany już zwyczaj przypisywania misjonarzy dworskich do personelu tej placówki, w której okolicach magnat przeważnie rezydował. Pomimo przynależności formalnej praktyka wyglądała niekiedy zupełnie inaczej. Na długotrwałe pobyty poza domem wskazuje dobitnie metryka listów. Na przykład Jan Poszakowski, mimo że był przypisany do personelu kolegium nieświeskiego, rezydował na dworze Anny Katarzyny w Białej, w odległości $300 \mathrm{~km}$ od macierzystej placówki ${ }^{164}$. Należący do tego samego domu Mikołaj Kuczewski mieszkał natomiast od schyłku 1758 do połowy 1761 r. w Warszawie, gdzie zawiadywał procesem toczącym się w nuncjaturze o unieważnienie małżeństwa Karola Stanisława „Panie Kochanku”. Przebywanie w takiej odległości od macierzystej placówki przyczyniało się niewątpliwie do osłabienia kontaktów z nią, jednak niekoniecznie przesądzało o upadku dyscypliny zakonnej i zaniku poczucia przynależności

${ }^{162}$ Na przykład Konrad Terpiłowski przyczynił się w decydujący sposób do pozyskania na katolicyzm żony Jana Mikołaja Aleksandra Radziwiłła, Henrietty Doroty z Przebendowskich, córki podskarbiego koronnego Jana Jerzego. Annuae collegii nesvisiensis 1709, ARSI, Lituania, nr 45, f. 48v.

${ }^{163}$ De confessariis..., w: Institutum..., t. 2, s. 260.

${ }^{164} \mathrm{Z}$ Białej pochodziły jego listy od 1726 do $1734 \mathrm{r}$. Zob. AGAD, AR, dz. V, nr 12212, passim. 
do Towarzystwa. W większych miastach zakonnicy mogli bowiem zamieszkiwać w budynkach klasztornych ${ }^{165}$. Zjawisko to pozwalało zachować zwierzchność przełożonego miejscowego domu nad kapelanem ${ }^{166}$.

$\mathrm{Z}$ pobytem poza placówką wiązało się przemieszczanie się $\mathrm{w}$ towarzystwie magnata. Oprócz funkcji reprezentacyjnych rola kapelana w czasie podróży polegała na zapewnianiu magnatowi stałej opieki duchowej, która przejawiała się w odprawianiu nabożeństwa, zwłaszcza wobec braku katolickiego kleru w miejscu pobytu ${ }^{167}$. Dla dalszych wypraw wymagane było pozwolenie ze strony generała. Świadczy o tym przypadek Krzysztofa Zalewskiego, spowiednika Albrychta Stanisława Radziwiłła, który w 1646 r. wyjechał do Wiecznego Miasta za wstępną zgodą generała Vincenzo Carafy ${ }^{168}$. O zezwolenie na wyjazdy ubiegano się również $\mathrm{w}$ przypadku podróży związanych z edukacją młodych magnatów ${ }^{169}$. O ile przykłady z połowy XVII w. wskazują na posiadanie przez generała pewnej kontroli nad mobilnością jezuitów związanych z magnatami, o tyle później rola przełożonych w Rzymie słabła, zwłaszcza w przypadku krótszych wyjazdów. Wraz z „Rybeńką” podróżowali na terenie Rzeczypospolitej jego kolejni kapelani nadworni: Feliks Wierzbicki ${ }^{170}$ i Mikołaj Kuczewski ${ }^{171}$. Na stałe u bogu Jana Mikołaja Aleksandra przebywał jego spowiednik Konrad Terpiłowski ${ }^{172}$. Wyjątek stanowił Hieronim Florian, który mimo posiadania kapelana nadwornego nie wzmiankował o jego towarzystwie w czasie podróży ${ }^{173}$. Dużą mobilnością wyróżniał się także Michał

${ }^{165}$ Do tego stwierdzenia uprawniają wzmianki o przebywaniu Mikołaja Kuczewskiego w kolegium akademickim w Wilnie podczas bytności „Rybeńki” w stolicy Wielkiego Księstwa. Diarium collegii Vilnensis 1752-1766, LVIA, f. 1135, ap. 20, nr 303, k. 64r-v, 104.

166 Tego typu powiązania były dostrzegane również przez osoby spoza zakonu. Na przykład Urszula z Branickich Lubomirska, pilnująca interesów córki podczas procesu „rozwodowego” przed sądem nuncjatury, skarżyła się na poczynania Kuczewskiego u Michała Kiełłpsza, rektora kolegium warszawskiego. Mikołaj Kuczewski do Michała Kazimierza Radziwiłła, Warszawa, 14 I 1761, AGAD, AR, dz. V, nr 7948/IV.

${ }^{167} \mathrm{Na}$ przykład Konrad Terpiłowski odprawiał mszę dla swego pryncypała, gdy ten wyjechał do Prus Książęcych. Diariusz Jana Mikołaja Radziwiłła (1704-1710), BN, nr II.9036, k. 48.

168 Vincenzo Carafa do Albrychta Stanisława Radziwiłła, do Wilna, 8 IX 1646, ARSI, Germania, nr 113a, s. 71; tenże do tegoż, Kowno, 21 XI 1646, ibidem, s. 78. Powrócił w marcu 1647 r. A.S. Radziwiłł, Pamiętniki, przeł. i oprac. A. Przyboś, R. Żelewski, t. 3, Warszawa 1980, s. 14.

${ }^{169} \mathrm{Na}$ wyjazd Jana Poszakowskiego ze swoim podopiecznym Hieronimem Florianem Radziwiłłem zgodził się generał już w 1731 r. Franciszek Retz do Michała Kazimierza Radziwiłła, Rzym, 9 VI 1731, ARSI, Germania, nr 117, f. 433. Ostatecznie jednak zakonnik pozostał w kraju. Hieronim Florian Radziwiłł do Anny Katarzyny Radziwiłłowej, Leśna Podlaska, 2 IV 1733, AGAD, AR, dz. IV, nr 116.

${ }^{170}$ Podczas podróży z „Rybeńką” do Wilna na trybunał, w kwietniu 1732 r. poświęcił kościół w Koreliczach. 14 marca 1734 r. „Rybeńko” wyprawił Wierzbickiego ze Stobiecka do Nieświeża na wieść o urodzeniu synów. AGAD, AR, dz. VI, nr II-80a, s. 487, 632.

171 Ibidem, s. 1801, 1852, 2107.

172 BN, nr II.9036, k. 12v, 29v, 48v.

${ }^{173}$ Zob. Hieronima Floriana Radziwiłła diariusze i pisma różne, oprac. M. Brzezina, Warszawa 1998. 
Woronicz jako spowiednik Karola Stanisława „Panie Kochanku”. To on w 1755 r. towarzyszył księciu podczas wjazdu na starostwo lwowskie, następnie był z nim w Wilnie, gdzie ten marszałkował trybunałowi, w Podhorcach Rzewuskich oraz na kadencji ruskiej trybunału w Mińsku ${ }^{174}$. Również w kolejnych miesiącach jezuita rezydował poza kolegium nieświeskim, do którego formalnie należał, zajmując się wspomnianym już procesem o unieważnienie małżeństwa „Panie Kochanku”, rozpoczętym w konsystorzu lwowskim ${ }^{175}$. Należy jeszcze wspomnieć o tym, że $\mathrm{w}$ okresie reformy szkolnictwa jezuickiego wyjazdy zagraniczne odbywali coraz częściej zakonnicy pełniący funkcje prywatnych nauczycieli ${ }^{176}$. Zwyczaj ten znacznie się przyczynił do poszerzenia horyzontów myślowych młodych jezuitów, którzy w przyszłości mieli odgrywać ważną rolę w utrwaleniu zmian w systemie oświaty ${ }^{177}$.

Ze względu na przynależność do bliższego otoczenia magnatów jezuici podejmowali na zlecenie chlebodawców wiele czynności niezwiązanych bezpośrednio z powołaniem zakonnym. Pierwszoplanową rolę odgrywali w utrzymywaniu kontaktów między dworem a instytucjami kościelnymi. Dotyczyło to przede wszystkim własnego zgromadzenia. Pomimo że kapelani nie udawali się na kongregacje prowincjalne $\mathrm{z}$ racji konieczności stałego przebywania $\mathrm{u}$ boku magnata ${ }^{178}$, odbywali oni niekiedy nieformalne spotkania $\mathrm{z}$ głównymi decydentami prowincji ${ }^{179}$. Ponadto podejmowali podróże do daleko położonych sanktuariów w celu oznajmienia woli dobroczyńców ${ }^{180}$. Kolejną dziedziną aktywności kapelanów były inicjatywy kulturalne, które miały na celu zaspokojenie ambicji politycznych chlebodawcy. W ten nurt wpisywała się działalność Mikołaja Kuczewskiego, który nie tylko zajmował się katalogowaniem księgozbioru ordynackiego ${ }^{181}$, ale

174 AGAD, AR, V, nr 18027, s. 34-118.

175 Duża część listów z tego okresu pochodziła ze Lwowa bądź okolicznych miejscowości, jak Podhorce, Fierlejówka lub Czartorysk. Ibidem, s. 119-184.

176 Na przykład Karol Wyrwicz towarzyszył Józefowi Hylzenowi do Wiednia, gdzie młody magnat miał kształcić się w Theresianum. Po ukończeniu nauki w tej ekskluzywnej placówce Wyrwicz przyjechał ponownie do stolicy habsburskiej, aby razem z podopiecznym udać się do Paryża. Obaj słuchali tam lekcji publicznych słynnego fizyka, jezuity Antoine Nolleta. Zob. Juozapo Jurgio Hilzeno 1752-1754 metu kelionés dienoraštis [Dziennik podróży Józefa Jerzego Hylzena z lat 1752-1754], oprac. A. Pacevičius, Vilnius 2013, passim.

177 S. Bednarski, op. cit., s. 58-67.

178 Podwójnie odmawiał udziału w kongregacji Konrad Terpiłowski - w 1705 i w 1711 r. ARSI, Congregationes, $\mathrm{nr} 86$, f. $337 \mathrm{v}$, nr 87, f. $113 \mathrm{v}$.

1797 maja 1753 r. Mikołaj Kuczewski jadł obiad w Wilnie razem z rektorem Akademii Janem Jurahą, z przełożonym mińskim Kazimierzem Jurahą, pińskim Ignacym Wilkinowiczem i nowogródzkim Franciszkiem Rościszewskim. LVIA, f. 1135, ap. 20, nr 303, k. 14v.

180 Takie zadanie spełnił na przykład spowiednik Anny Katarzyny z Sanguszków, Kazimierz Stankiewicz, który we wrześniu 1743 r. został wysłany do Studzianny (ok. 220 km od Białej) w celu poinformowania tamtejszych filipinów o donacji planowanej przez magnatkę na rzecz klasztoru. AGAD, AR, dz. XI, nr 122, s. 85-87.

181 Podpisany przez niego katalog zachował się w Warszawie. AGAD, AR, Rękopisy Biblioteczne, I-6/N-866. 
też publikował bez ujawnienia własnego nazwiska kilka tekstów skierowanych do szerszej publiczności ${ }^{182}$. W porównaniu ze wspomnianymi przedsięwzięciami, znikome było zaangażowanie jezuickich kapelanów w życie polityczne, o czym świadczy przede wszystkim brak zainteresowania życiem sejmikowym. Jedyną sferę aktywności, która wiązała się częściowo z polityką, stanowiło zawiadywanie staraniami o unieważnienie małżeństwa swoich protektorów. W realiach dawnej Rzeczypospolitej kwestia ta miała wymiar nie tylko rodzinny. Ze względu na sprawy majątkowe $\mathrm{z}$ nią związane nabierała rozgłosu politycznego, decydując o sojuszach między rodami magnackimi. W te zabiegi jezuici byli niekiedy angażowani przez samych magnatów, którzy wysoko cenili ich znajomość prawa kanonicznego i tajników kościelnego wymiaru sprawiedliwości. Podejmując działania zgodnie z oczekiwaniami chlebodawców, jezuici musieli liczyć się z szeroko pojętym kontekstem politycznym ${ }^{183}$.

Jezuiccy kapelani nadworni nie tylko świadczyli bezinteresownie rozmaite usługi, ale również czerpali dla siebie i swego otoczenia pewne korzyści. Dzięki obecności na dworze magnackim mieli możliwość poszerzenia horyzontów intelektualnych poza ścisłe ramy formacji zakonnej. Uwaga ta dotyczy szczególnie okresu sprzed reformy szkolnictwa jezuickiego, gdy program nauczania, w dużym stopniu jeszcze oparty na założeniach Ratio studiorum, pozostawiał niewiele szans na przekazywanie zdobyczy nowoczesnych dyscyplin naukowych. Poszerzenie kompetencji kulturowych zakonników łączyło się nie tylko z doszlifowaniem umiejętności językowych, o czym już wspomniano, ale również z pisaniem prac na tematy związane $\mathrm{z}$ innymi dziedzinami wiedzy. Na przykład, w okresie pełnienia służby jako wychowawca Hieronima Floriana, Jan Poszakowski zaczął rozwijać swoje zamiłowania historiograficzne. Na potrzeby podopiecznego przepisywał bowiem biografię Bogusława Radziwiłła, pióra arianina Samuela Przypkowskiego i Zbigniewa Morsztyna ${ }^{184}$, a także przekładał z łaciny na polski Pamiętniki

${ }^{182}$ W 1748 r. ukazało się Żołnierskie nabożeństwo powołaniu wojskowych ludzi właśnie służące, stanowiące połączenie Nabożeństwa żotnierskiego Piotra Skargi i dzieł belgijskiego kapelana obozowego Thomasa Sailly’ego. 12 lat później Poszakowski opublikował Order dam Krzyża Gwiaździstego to jest historia postanowienia tego orderu, jego ustawy, święta, i zwykłe nabożeństwa, będący tłumaczeniem L’Ordre des dames de la Croix de l'étoile Jana Kaspra Leidenmayra (Linz 1726).

${ }^{183}$ Na przykład w kontekście starań o wspomniany już rozwód Mikołaj Kuczewski stał się gorącym zwolennikiem współpracy z Jerzym Wandalinem Mniszchem, który w oparciu o Radziwiłłów dążył do utworzenia partii dworskiej na Litwie, przeciwstawiającej się Czartoryskim. Mikołaj Kuczewski do Michała Kazimierza Radziwiłła, Warszawa, 5 XII 1760, AGAD, AR, dz. V, nr 7948/IV. Zob. też: M. Czeppe, Kamaryla pana z Dukli: ksztattowanie się obozu politycznego Jerzego Augusta Mniszcha: 1750-1763, Warszawa 1998, s. 106-111.

${ }^{184}$ Do tego stwierdzenia uprawnia porównanie duktu pisma rękopisu Biblioteki Kórnickiej (nr 354), pochodzącego z końca lat 20. XVIII w., z oryginalnymi listami Poszakowskiego (AGAD, AR, dz. V, nr 12212; ibidem, Zbiór Czołowskiego, nr 585; LMAB, f. 139, nr 3591). Na temat biografii Bogusława Radziwiłła zob.: J. Pelc, Zbigniew Morsztyn, Wrocław 1966, s. 11-17; T. Wasilewski, 
Albrychta Stanisława Radziwiłła ${ }^{185}$. Pierwotne zainteresowania dziejami rodu Radziwiłłów ewoluowały później w kierunku historii powszechnej i kościelnej, co znalazło odzwierciedlenie w wydaniu pierwszych kalendarzy politycznych na Litwie oraz pism polemicznych skierowanych przeciw jansenizmowi i masonerii1 ${ }^{186}$.

Istotnym aspektem oddziaływania jezuitów na środowisko dworskie było ich wstawiennictwo za osobami trzecimi. Pomimo że prawodawstwo zakonne zabraniało tego typu rekomendacji, bywały one na porządku dziennym. Dzięki protekcji Mikołaja Kuczewskiego jego brat Marcin robił świetną karierę wojskową na dworze „Rybeńki”. Zakonnik aktywnie starał się o jego awans, polecając go m.in. do funkcji deputata wojska litewskiego na sejm ${ }^{187}$. Z kolei Michał Woronicz angażował się na rzecz owdowiałej siostry, prosząc „Panie Kochanku”, aby poskromił wierzycieli i pozostawił w jej rękach dobra zastawne Medwezy ${ }^{188}$.

Długoletnie relacje kapelana nadwornego z dworem sprzyjały silnemu utożsamianiu się z interesem chlebodawcy. Na tym tle więzi nabierały wymiaru emocjonalnego, który zaznaczał się w momencie, gdy starzejący się spowiednik domagał się opieki zdrowotnej i wsparcia materialnego. Widać to wyraźnie na przykładzie korespondencji Michała Woronicza, który nie tylko czekał na powrót „Panie Kochanku” do ojczyzny, ale też prosił o pozwolenie na korzystanie $\mathrm{z}$ wód termalnych w Cieplicach i dziękował za zgodę na mieszkanie podczas choroby w zamku nieświeskim ${ }^{189}$.

Podsumowując, należy stwierdzić, że jezuiccy misjonarze dworscy stanowili wąską, choć znaczącą grupę wśród personelu zakonnego od momentu stabilizacji jego struktury administracyjnej, wraz z utworzeniem prowincji litewskiej w 1608 r., aż do kasaty Towarzystwa. Sytuacja ta wyróżniała dawną Rzeczpospolitą

Uwagi wstępne, w: Autobiografia Bogusława Radziwiłła, oprac. T. Wasilewski, Warszawa 1979, s. $102-103$.

185 „Memoryjał rzeczy znaczniejszych, które się w Polszcze działy od śmierci Zygmunta III od roku pańskiego 1632 aż do roku 1652 [1653] spisany po łacinie przez [...] książęcia jm. Albrychta Stanisława Radziwiłła, kanclerza wielkiego W. Ks. Litewskiego, a przez [...] książęcia jm. Hieronima Floriana Radziwiłła [...] na polski język przetłumaczony roku pańskiego 1731”. Zakład Narodowy im. Ossolińskich we Wrocławiu, nr 118/II.

${ }^{186}$ Przeciw jansenistom opublikował polemikę pt. Absurda jansenistica (Warszawa 1754). Tekst zwalczający masonerię nie został wydany drukiem. Wobec zaginięcia rękopisu zachowały się tylko opinie cenzorów zakonnych. ARSI, Fondo Gesuitico, nr 674, f. 121-124. Odnośnie do kalendarzy zob.: R. Jakubėnas, $Z$ historii kalendarzownictwa $w$ Wielkim Księstwie Litewskim w XVIII wieku. Kalendarze wileńskie ks. Jana Poszakowskiego, w: Literatura, historia, dziedzictwo. Prace ofiarowane Profesor Teresie Kostkiewiczowej, red. T. Chachulski, A. Grześkowiak-Krwawicz, Warszawa 2006, s. 398-406; J. Żukowska, Kalendarze Jana Poszakowskiego jako źródło edukacji historycznej, w: Między barokiem a oświeceniem. Edukacja, wykształcenie, wiedza, red. S. Achremczyk, Olsztyn 2005, s. 111-121.

${ }^{187}$ Mikołaj Kuczewski do Michała Kazimierza Radziwiłła, Wilno, 11 VII 1750, AGAD, AR, V, nr 7948/II.

${ }^{188}$ Michał Woronicz do Karola Stanisława Radziwiłła, Biały Kamień, 14 IX 1770; ibidem, 3 I 1771; Pińsk, 20 IV 1771, ibidem, nr 18027.

189 Tenże do tegoż, Nieśwież, 4 II 1768, ibidem. 
wśród krajów zachodnioeuropejskich, w których w XVIII w. zmniejszyła się liczba kapelanów nadwornych w konsekwencji wzrostu popularności jansenistycznych i febroniańskich nurtów umysłowych oraz w wyniku stopniowego ograniczania wpływów jezuickich w świecie kultury i oświaty. Znaczenie jezuickich kapelanów nadwornych w kontekście badań nad społecznym oddziaływaniem Kościoła katolickiego polegała na ich roli jako swoistego rodzaju łącznika pomiędzy Towarzystwem a elitami społecznymi. $Z$ jednej strony pośredniczyli oni w relacjach władców lub dostojników państwowych z przełożonymi zakonnymi, z drugiej zaś ułatwiali kontakty między dobroczyńcami a poszczególnymi placówkami. Poziom zaangażowania jezuickich kapelanów w życie określonych rodów odzwierciedlał nie tylko intensywność relacji zakonu z protektorami, ale także konstelację sił politycznych $\mathrm{w}$ danym okresie. W większej skali można zauważyć, że aktywność w kręgu magnatów rozwinęła się kosztem posługi duszpasterskiej świadczonej na rzecz dworu królewskiego, co szło w parze z decentralizacją i osłabianiem władzy monarszej. W mniejszej skali widoczna jest tendencja do kierowania duszpasterstwa jezuickiego do otoczenia tych magnatów, którzy w danym momencie cieszyli dużym znaczeniem politycznym.

Obecność jezuickich kapelanów w kręgu magnatów wywierała również znaczny wpływ na funkcjonowanie zakonu, co zaznaczało się zarówno w świetle decyzji podejmowanych przez władze zakonne w kwestiach polityki personelu, jak i w perspektywie indywidualnej, głównie w związku z karierą poszczególnych ojców Towarzystwa. W przypadku pierwszego aspektu widoczne jest dążenie do spełniania oczekiwań protektorów domagających się przysłania jezuickich duszpasterzy na dwór. Elastyczność zachowywano także w kwestii przestrzegania obowiązku rezydowania w klasztorze. Służba dworska powodowała ponadto poszerzenie horyzontów kulturowych i umiejętności językowych zakonników, a także sprzyjała ich dalszej karierze w zakonie, o czym świadczy piastowanie urzędów kierowniczych przez byłych misjonarzy dworskich. Na wspomniane zjawiska nie powinno się jednak patrzeć w kategorii uzależnienia zakonu od woli dobroczyńców. Niekiedy przełożeni potrafili bowiem odmówić prośbom magnatów, którzy ubiegali się o wyznaczenie kapelana. Nie wynikało to $\mathrm{z}$ braku szacunku lub lekceważenia pozycji społecznej zamożnych protektorów, lecz z troski o świadczenie posługi w innych środowiskach społecznych. Pomimo elastyczności wobec prawodawstwa zakonnego istniały również kwestie, w których zasadniczo nie ustępowano. Na przykład w wypadku utrzymania beneficjów kościelnych jezuiccy kapelani nadworni musieli natychmiast wystąpić z zakonu.

Ostrożnie należy mówić o przynależności misjonarzy dworskich do duchownej klienteli magnatów, w której skład tradycyjnie wchodził kler parafialny, ściśle uzależniony od właściciela ziemskiego z powodu posiadanych prebend. Niewątpliwie relacje zakonników z chlebodawcą przypominały niekiedy stosunki kliencko-patronackie. Zwłaszcza w przypadku jezuitów piastujących urząd kapelana nadwornego 
przez kilkanaście lub kilkadziesiąt lat rozwijała się silna więź emocjonalna z protektorem, dochodziło do stopniowego wkomponowywania się zakonnika w środowisko dworskie oraz do utożsamiania się z jego wartościami. Takie kariery stanowiły jednak wyjątek. Większość duszpasterzy pełniła bowiem służbę dworską przez stosunkowo krótki okres. Po jej ukończeniu relacje z magnatem słabły. Fakt ten pozwala stwierdzić, że służba dworska odgrywała rolę tymczasowego etapu kariery zakonnej: wpływała na dalsze awanse, choć nie decydowała o nich w wyłączny sposób. Wobec tego Towarzystwo jako zgromadzenie zachowywało znaczny margines autonomii. Wyznaczanie misjonarzy dworskich przyczyniało się do podtrzymywania tej samodzielności, tworząc swoistego rodzaju przestrzeń buforową, w której ramach można było osiągnąć kompromis między ideałami zakonu a oczekiwaniami elit.

\section{Court chaplains in the Lithuanian Province of the Society of Jesus. Between Order legislation and everyday practice Summary}

This article analyzes the activity of Jesuit preachers, confessors and private teachers at the king's and noblemen's courts in the Early Modern Poland. The first part focuses on the legislation concerning court chaplains at the turn of the $16^{\text {th }}$ century. The author sketches then a collective portrait of court preachers, confessors and teachers belonging to the Lithuanian Province throughout the $17^{\text {th }}$ and $18^{\text {th }}$ century. In doing so, he presents the reciprocal influence between the Jesuit Order and its benefactors and proofs how far general rules were applied in this specific context. In spite of the marginalization of Lithuanian Jesuits at the royal court, the number of chaplains remained high. This was possible thanks to an increasing presence in the entourage of high nobility. Within this social layer many confessors and preachers were associated with the Radziwiłł and the Sapieha families. Even though in some cases Jesuit priests were engaged at court for many years, the tasks of confessor and preacher were usually performed for a short time by relatively young members of the Society of Jesus. Pastoral activity in the entourage of aristocracy represented therefore an early stage of the religious career. Among the features that made a certain Jesuit suitable to the post of court chaplain there were allegiance to his patron, relatively low social origin as well as a good knowledge of foreign languages, in particular French. In the end some aspects of the life of Jesuit court priests are sketched, such as the tasks unrelated to pastoral activity performed on behalf of their protectors and the emotional side of their relationship with them.

\section{Bibliografia}

\section{Źródła rękopiśmienne}

Archivum Romanum Societatis Iesu (Rzym)

Congregationes: $\mathrm{nr} 20 \mathrm{~b}$

Lituania: $\mathrm{nr} 3,6,45,56-58,62,64$

Germania: $\mathrm{nr} 34,113 \mathrm{a}, 116,117$

Polonia: $\mathrm{nr} 45,69$

Fondo Gesuitico: nr 674 
Archiwum Główne Akt Dawnych (Warszawa)

Archiwum Radziwiłłów

Dział IV: nr 116

Dział V: nr 1047, 1067, 6202/I, 7948/II, 7948/IV, 11551, 12212, 18027

Dział VI: nr II-80a

Dział XI: nr 122

Rękopisy Biblioteczne: I-6/N-866

\section{Zbiór Czołowskiego}

nr 585

Biblioteka Narodowa (Warszawa)

nr II.9036

Biblioteka Kórnicka Polskiej Akademii Nauk nr 354

Zakład Narodowy im. Ossolińskich (Wrocław)

nr 118/II

Lietuvos Valstybès Istorijos Archyvas (Wilno)

Fondas 1135: ap. 20, nr 303

Fondas 1276: ap. 2, nr 110

Lietuvos Mokslų Akademijos Vrublevskių Biblioteka (Wilno)

Fondas 139: nr 3591, 5340

\section{Źródła drukowane}

Autobiografia Bogusława Radziwiłła, oprac. T. Wasilewski, Warszawa 1979.

Fontes Historiae Latviae Societatis Iesu. Latvijas vēstures avoti jezuītu ordena archivos, red. J. Kleijntjenss, t. 1-2, Rīga 1940-1941.

Hieronima Floriana Radziwiłła diariusze i pisma różne, oprac. M. Brzezina, Warszawa 1998.

Institutum Societatis Iesu, t. 1-2, Praga 1757.

Juozapo Jurgio Hilzeno 1752-1754 metu kelionès dienoraštis [Dziennik podróży Józefa Jerzego Hylzena $z$ lat 1752-1754], oprac. A. Pacevičius, Vilnius 2013.

Konstytucje Towarzystwa Jezusowego wraz z przypisami Kongregacji Generalnej XXXIV oraz normy uzupetniające zatwierdzone przez tę samą Kongregację, Kraków 2001.

Loyola I., Ćwiczenia duchowne, przeł. J. Ożóg, Kraków 1996.

Matuszewicz M., Diariusz życia mego, oprac. B. Królikowski, Z. Zielińska, t. 1-2, Warszawa 1986.

Mieleszko M., Emblematy, wyd. i oprac. R. Grześkowiak, J. Niedźwiedź, Warszawa 2010.

Obras Completas de San Ignacio de Loyola, red. I. Iparraguirre, wyd. 2, Madrid 1963.

Radziwiłł A.S., Pamiętniki, przeł. i oprac. A. Przyboś, R. Żelewski, t. 3, Warszawa 1980.

\section{Opracowania (wybór)}

Bednarski S., Upadek i odrodzenie szkół jezuickich w Polsce. Studium z dziejów kultury i szkolnictwa polskiego, Kraków 1933 (reprint: 2003). 
Bernatowicz T., Miles Christianus et peregrinus. Fundacje Mikołaja Radziwiłła „Sierotki” w ordynacji nieświeskiej, Warszawa 1998.

Bireley R., The Jesuits and the Thirty Years War: Kings, Courts, and Confessors, Cambridge 2003.

Czamańska I., Wiśniowieccy. Monografia rodu, Poznań 2007.

Czeppe M., Kamaryla pana z Dukli: kształtowanie się obozu politycznego Jerzego Augusta Mniszcha: 1750-1763, Warszawa 1998.

Duhr B., Die Jesuiten an den deutschen Fürstenhöfen des 16. Jahrhunderts, Freiburg am Breisgau 1901.

Duhr B., Geschichte der Jesuiten in den Ländern Deutscher Zunge im 18. Jahrhundert, t. 4, cz. 1, München-Regensburg 1928.

Encyklopedia wiedzy o jezuitach na ziemiach Polski i Litwy 1564-1995, red. L. Grzebień, Kraków 1996.

Fabre J., Stanislas-Auguste Poniatowski et l'Europe des Lumières. Étude de cosmopolitisme, Paris 1952.

Friedrich M., Der lange Arm Roms? Globale Verwaltung und Kommunikation im Jesuitenorden 1540 1773, Frankfurt am Main-New York 2011.

Friedrich M., Politikberatung durch Intellektuelle? Das Verhältnis des Jesuitenordens zu den frühneuzeitlichen Fürstenhöfen im Spiegel von Giulio Negronis Traktat „Aulicismus, sive de fuga aulae dissertatio", w: Intellektuelle in der Frühen Neuzeit, wyd. L. Schorn-Schütte, Berlin 2011, s. 175-209.

Grzebień L., Józef Andrzej Załuski i jezuici, „Roczniki Teologiczno-Kanoniczne” 1984, t. 31, z. 4, s. $55-70$.

Kempa T., Mikołaj Krzysztof Radziwiłł Sierotka (1549-1616) wojewoda wileński, Warszawa 2000.

Kopiec J., Między Altransztadem a Poltawą. Stolica Apostolska wobec obsady tronu polskiego w latach 1706-1709, Opole 1997.

Kurkowski J., Z dziejów polskiego edytorstwa źródeł historycznych. Maciej Dogiel (1715-1760), „Analecta. Studia i Materiały z Dziejów Nauki", R. 15, 2006, z. 1-2, s. 89-149.

Lesiński J., Spory o dobra neuburskie, „Miscellanea Historico-Archivistica” 1996, t. 6, s. 95-132.

Manteuffel G., O starodawnej szlachcie krzyżacko-rycerskiej na kresach inflanckich, Lwów 1910.

Mariani A., Jezuici w Inflantach i w Kurlandii (1700-1773). Między wielka polityka a elita lokalna, „Zapiski Historyczne” 2012, t. 77, z. 4, s. 113-138.

Mariani A., Personaleinsatz und -mobilität in der litauischen Provinz der Gesellschaft Jesu im 18. Jahrhundert, ,Zeitschrift für Ostmitteleuropaforschung”, R. 63, 2014, z. 2, s. 163-213.

Niesiecki K., Herbarz polski Kaspra Niesieckiego S.J.: powiększony dodatkami z poźniejszych autorów, rękopismów, dowodów urzędowych, wyd. J.N. Bobrowicz, t. 1-10, Lipsk 1839-1845.

Obirek S., Jezuici na dworach Batorego i Wazów. Wplyw kapelanów dworskich i wychowawców ksiażąt na postawy panujących i politykę państwa 1580-1668, Kraków 1996.

Olivares E., Los coadjutores, espirituales y temporales, de la Compañía de Jesús. Su origen y sus votos, „Archivum Historicum Societatis Iesu”, R. 33, 1964, nr 65, s. 102-121.

Pelc J., Zbigniew Morsztyn, Wrocław 1966.

Piwarski K., Pierwsze stosunki Augusta II ze Stolica Apostolską, „Polityka Narodów” 1937, t. 9, z. 6, s. 513-545.

Polonica w Archiwum Rzymskim Towarzystwa Jezusowego, red. A. Bieś i in., t. 2: Lituania, Kraków 2003.

Polski Słownik Biograficzny, t. 1-49, Kraków [i in.] 1935-2014.

Puchowski K., Jezuickie kolegia szlacheckie Rzeczypospolitej Obojga Narodów. Studium z dziejów edukacji elit, Gdańsk 2007.

Rok B., Marcin Kurzeniecki (1705-1768). Jezuici wileńscy wobec Kościoła Unickiego w połowie XVIII wieku, w: Studia wschodnie, red. K. Matwijowski, Wrocław 1993, s. 49-55.

Rostworowski E., Religijność i polityka wyznaniowa Stanisława Augusta, w: Życie kulturalne i religijność w czasach Stanisława Augusta Poniatowskiego, red. M.M. Drozdowski, Warszawa 1991, s. 11-24. 
Seredyka J., Pińsk Albrychta Stanisława Radziwiłła, w: Kultura polityczna w Polsce. Praca zbiorowa,

t. 6: Litwa w polskiej tradycji i kulturze politycznej, cz. 1, red. M. Kosman, Poznań 2006, s. 37-49. Słownik polskich teologów katolickich, red. H.E. Wyczawski, t. 4, Warszawa 1983.

Staszewski J., August III Sas, Wrocław 2010.

Staszewski J., Stosunki Augusta II z Kuriq Rzymską w latach 1704-1706, „Roczniki Towarzystwa Naukowego w Toruniu", R. 71, 1966, z. 1.

Załęski S., Jezuici w Polsce, t. 1-4, Lwów-Kraków 1900-1905.

Andrea Mariani - dr; ukończył studia z zakresu historii na Wydziale Literatury i Filozofii Uniwersytetu Państwowego w Mediolanie. W październiku 2015 r. obronił rozprawę doktorską pt. Jezuici $w$ kręgu Radziwiłłów nieświeskich $w$ XVIII wieku. Społeczna i kulturowa rola kolegiów w Nieświeżu $i$ w Stucku, napisaną na Wydziale Historycznym Uniwersytetu im. Adama Mickiewicza w Poznaniu. Interesuje się dziejami Towarzystwa Jezusowego, dworami magnackimi i kulturą elit w dawnej Rzeczypospolitej. E-mail: mariani.andrea86@gmail.com 